\title{
Motivasyon araçlarının örgütsel bağlılık üzerine etkisi: Perakende sektörü çalışanlarına yönelik bir araştırma
}

\section{Effect of motivation tools on organizational commitment: A research for retail sector employees}

\author{
Medine $Y_{1} 1 m a z^{1}$ \\ Pelin Vardarlier ${ }^{2}$
}

${ }^{1}$ Bahçeşehir Üniversitesi, İstanbul, Türkiye mdnylmz86@gmail.com

ORCID: 0000-0002-8430-708X

2 Doç. Dr., İstanbul Medipol Üniversitesi,
İstanbul, Türkiye, pvardarlier@medipol.edu.tr

ORCID: 0000-0002-5101-6841

\section{Sorumlu Yazar/Corresponding Author:}

Pelin Vardarlier,

İstanbul Medipol Üniversitesi, İstanbul, Türkiye, pvardarlier@medipol.edu.tr

Başvuru/Submitted: 28/07/2021

Revizyon/Revised: 30/09/2021

Kabul/Accepted: 10/10/2021

Yayın/Online Published: 25/12/2021

Atıf/Citation: Yılmaz, M., \& Vardarlier, P., Motivasyon araçlarının örgütsel bağlllık üzerine etkisi: Perakende sektörü çalışanlarına yönelik bir araştırma, bmij (2021) 9 (4): 1347-1365, doi: https://doi.org/10.15295/bmij.v9i4.1900

\section{Öz}

Perakende sektörü Türkiye' de hizmet ve satın alma seçeneklerini yenileyerek gelişen ve birçok insana istihdam sağlayan bir sektördür. Bu kapsamda çalıșmanın amacı Türkiye'nin önemli perakende şirketlerinden birinin çalışanlarına yönelik motivasyon araçları ile örgütsel bağlılık arasındaki ilişkiyi belirlemektir. Aynı zamanda demografik özelliklere göre bu iki etmen arasındaki farklılıklar analiz edilmiştir. Yapılan analizler sonucunda cinsiyete göre içsel ve dışsal motivasyon araçları, kadınlarda daha yüksek iken; içsel motivasyon araçlarının evli bireylerde daha yüksek olduğu; motivasyon ve dışsal motivasyon araçları ortalamasının genç ve yaşça büyük bireylerde daha yüksek olduğu tespit edilmiştir. Örgütsel bağlllık bakımından ise örgütsel bağlllığın yüksek lisans düzeyinde alt seviyedeki eğitim derecesine göre daha düşük olduğu; duygusal bağlllı̆̆ın ilgili şirketteki deneyim arttığında ise arttığı gözlemlenen önemli sonuçlardandır. İlişki analizleri sonucunda ise örgütsel bağlllığın (duygusal bağlılık, normatif bağlllık ve devam bağlllığı), motivasyon araçları (içsel ve dışsal motivasyon araçları) ile arasında pozitif ve anlamlı bir ilişki olduğu görülmüştür. Motivasyon araçları ile örgütsel bağlllık, duygusal bağlllık, normatif bağlllık, içsel motivasyon ve dışsal motivasyon ile arasında anlamlı ve pozitif bir ilişki olduğu görülmüştür. Son olarak yapılan regresyon analizleri sonucunda motivasyon araçları ve örgütsel bağlılık arasındaki çift yönlü ilişki kanıtlanmıştır.

Anahtar Kelimeler: Motivasyon Araçları, Örgütsel Bağlllık, Perakende Sektörü

Jel Kodlari: J10, M12, M54

\begin{abstract}
The retail industry is evolving and renewing service purchase options in Turkey, and it is a sector that employs many people. In this context, the aim of the study with motivational tools for employees of one of Turkey's major retail companies is to determine the relationship between organizational commitment. At the same time, the differences between these two factors were analyzed according to demographic characteristics. As a result of the analysis, while intrinsic and extrinsic motivation tools are higher for women, innate motivation tools are higher in married individuals. Furthermore, the average and irrelevant motivation tools are more elevated in young and older individuals. In terms of organizational commitment, organizational commitment is lower at the master's level than the lower education level; It is one of the actual results observed that emotional attachment increases when experience in the relevant company increases. As a result of the relationship analysis, it was seen that there is a positive and significant relationship between organizational commitment (emotional commitment, normative commitment and continuance commitment) and motivation tools (intrinsic and extrinsic motivation tools). Furthermore, it was observed that there was a significant and positive relationship between motivation tools and organizational commitment, emotional commitment, normative commitment, intrinsic motivation and extrinsic motivation. Finally, as a result of the regression analysis, the two-way relationship between motivation tools and organizational commitment has been proven.
\end{abstract}

Keywords: Motivation Tools, Organizational Commitment, Retail Industry

Jel Codes: J10, M12, M54 


\section{Extended Abstract}

\section{Effect of motivation tools on organizational commitment: A research for retail sector employees}

\section{Literature}

Although studies are examining the relationship between motivation tools and organizational commitment, it has been revealed by many studies in the domestic and foreign literature that these two concepts are related. Some of the studies conducted in this direction and their results were examined; Bilge et al. (2015) investigated the relationship between intrinsic and extrinsic motivation and organizational commitment. As a result of the analysis, outside motivation factors positively affect inherent motivation and positively affect continuance commitment, affective commitment, and normative commitment, which are the subfactors of organizational commitment. On the other hand, it has been concluded that it hurts emotional commitment. In another study, Ertit (2019) examined relationships between motivation, personality traits and organizational commitment that were significantly lower. The most vital relationship was found between normative commitment and agreeableness and intrinsic motivation and perceptions of responsibility. As a result of the study, Canbaba (2019) determined a positive, close to high relationship between cause and organizational commitment. It is seen that motivation has a significant effect on organizational commitment, and stimulation increases the level of organizational commitment. As a result of the research, the cause and organizational commitment of the employees are high; It was concluded that the relationship between motivation and organizational commitment was positive. According to the information obtained from all these studies; The relationship between organizational commitment and motivation tools was investigated according to personality and demographic characteristics in different sectors. In addition, the relationship between motivation and organizational commitment was examined in general. As a result, it was concluded that there is a positive relationship between the basis of the employees and their organizational commitment.

\section{Research subject}

The research subject emphasises the effect of Motivation Tools on Organizational Commitment.

\section{Research purpose and importance}

Within the scope of the study, it is aimed to examine the motivation tools and organizational commitment levels of the employees of the retail sector, which has significant contributions to the Turkish economy, whether these levels change according to demographic characteristics, whether there is a difference between generations and the relationships between motivation tools and organizational commitment.

\section{Contribution of the article to the literature}

Since this study is specific to the retail sector, it is thought to directly contribute to the human resources managers working on policy implementations based on the industry. Therefore, it is crucial to examine the research results in this direction.

\section{Design and method}

The research was conducted by sending an electronic questionnaire to one of the leading companies in the retail sector in Turkey, covering the months of January-April 2019. The questionnaire link was sent to a mass mailing list by e-mail, and feedback was received from the employees. In this sense, since each employee has an equal probability of answering the questionnaire, the study sample was created based on simple random sampling. The research universe consists of employees in the retail sector in Istanbul. A total of 216 employees were reached, and the survey was terminated.

Regarding the scales of the study, the organizational commitment scale developed by Meyer and Allen (1991) was used. In the measurement of motivation tools, Dündar et al. (2007) by Mottaz (1985), Brislin et al. (2005), the motivation tools scale, which was created by using the essential scales in the studies of Mahaney and Lederer (2006), was used. In the research, descriptive statistics were first included in introducing the data. Afterwards, the Cronbach's alpha ( $\alpha$ ) reliability values of the scales were calculated. In addition, confirmatory factor analysis was performed to check whether the sub-dimensions of the scales fit with the theory. After this step, whether the measured motivation tools and organizational commitment scales change according to the demographic characteristics of the employees were examined with the help of Anova (or Kruskal Wallis) and t-test (or Mann Whitney test) according to the results of the normality test. Finally, regression/correlation analysis examined the relationship between organizational commitment and motivation tools. All these analyzes were made in SPSS 22 and AMOS 22 package programs.

\section{Research type}

In this research, the quantitative data collection method has been used.

\section{Findings and discussion}

It has been observed that these scores of motivation tools, intrinsic and extrinsic motivation tools are higher in women according to gender. The mean of innate motivation tools was higher in married people. 18-23 age group, 24-19 age group and 30-39 age group; It has been observed that the average of motivation and extrinsic motivation tools scores of those in the age group of 5059 is higher than those in the age group of 24-29 and 30-39. It has been observed that the emotional commitment scores of the employees in the 40-49 age range are higher than those in the 24-29 age groups. It has been observed that organizational commitment is lower at the graduate level than those at the lower level of education. The emotional burden was higher at the high school level than at the graduate level. Finally, a normative commitment was higher at the undergraduate level than at the graduate level. It has been observed that there is a positive and significant relationship between organizational dedication, emotional commitment, continuance commitment, normative commitment, motivational tools, and intrinsic and extrinsic motivation tools. It has been observed that there is a positive and significant relationship between motivation tools and organizational dedication, emotional commitment, normative commitment, intrinsic motivation and extrinsic motivation. The relationship between motivational tools and organizational commitment is bidirectional and significant rather than unidirectional. 


\section{Conclusion, recommendation and limitations}

The retail industry is a developing industry in Turkey and employs many people by offering service and purchasing options. For this reason, it is crucial to examine the motivation and organizational commitment relations of the retail sector employees. In addition, reading employees using difference and similarity analysis according to their motivation tools and organizational commitment will guide employers in the sector. This situation will be reflected in human resources policies in the form of improvements. When the studies in the literature are examined, besides the studies supporting the results, some studies contradict the results. For example, bilge et al. (2015) concluded that while extrinsic motivation positively affects the sub-factors of organizational commitment, internal motivation hurts the sub-factors of organizational commitment. This study observed that both intrinsic and extrinsic motivation tools had a positive and significant effect on the sub-factors of organizational commitment (except for continuance commitment). In another study, Keskin (2019) concluded a positive and meaningful relationship between organizational commitment and the dimensions that make up the motivation factors. This result is similar to the results in this study. As mentioned before, although the results obtained differ from each other as the studies conducted in the literature differ in terms of both the sector and time in which they are applied, the results obtained in general also say that motivation tools affect increasing organizational commitment. This study also supports these results.

As a result of the analysis, while intrinsic and extrinsic motivation tools are higher for women, innate motivation tools are higher in married individuals. The average and irrelevant motivation tools are more elevated in young and older individuals. In terms of organizational commitment, organizational commitment is lower at the master's level than the lower education level; It is one of the critical results observed that emotional attachment increases when experience in the relevant company increases.

In terms of organizational commitment, the fact that organizational commitment is lower at the master's level than those at the lower level of education indicates that the responsibility decreases as the level of education increases. In this case, organizational commitment should be strengthened by applying a different human resources policy for high education levels. In terms of emotional commitment, those who work less than two years have less dynamic obligation than those who work between 16-20 years; Employees between 2-4 years have lower emotional commitment scores than employees between 8-10 and 16-20 years, and passionate commitment of employees between 5-7 years is lower than that of employees between 16-20 years, affective organizational commitment is temporally determined in the same company. Therefore, more employees in the company establish more emotional commitment. This is a common situation. However, policies are needed to increase organizational commitment for employees with fewer years of experience. Implementing procedures for this and similar differences will create a domino effect due to the positive bidirectional relationship between motivational tools and organizational commitment, which will increase organizational commitment and motivation.

\section{Limitations of the article}

The research limitations, the difficulties of the employees in understanding some questions, the difficulty in finding the time necessary for the employees to fill the questionnaire due to the busy working hours of the retail sector extended the data collection period. It is thought that this study will contribute to the direction of human resources managers in the retail industry. In addition, other scales can be included in this study, and more complex relationships can be examined in future studies. 


\section{Giriş}

Perakendecilik sektörü, insanların ihtiyaçlarının karşılandığı önemli bir pazar durumundadır. Bu nedenle kendi sektörünün yanında diğer sektörleri de kapsayarak gerek mikro yapıda gerekse makro yapıda büyümeye önemli katkıları olan bir sektördür. Nitekim perakende sektörü ülkelerin makroekonomik durumlarına katkılarının yanı sıra ülkelerin makroekonomik durumlarından da kolayca etkilenebildiği için kırılganlığa müsait bir sektördür. Örneğin, enflasyonun yüksek olması tüketicilerin satın alma gücünü etkilediğinden perakende sektörünü de etkilemektedir. Öte yandan ise teknolojik gelişmelerle birlikte yeni servis olanakların artması ve değişen tüketici davranışlarına uyum sağlanmasıyla son yıllarda perakendecilik sektörünün işlevi daha da yaygınlaşmıştır. Sektörün büyüme potansiyelinin fazla olması istihdama da açık olduğunun göstergesidir. Dünya çapında 27 şehir üzerinde yapılan bir araştırmaya göre dünyada 2012-2025 arasında perakende ve toptan satış sektöründe net 1,6 milyon ek iş fırsatı imkânı olacağı tahmin edilmektedir (PWC, 2016). Türkiye'de perakende sektöründe yaklaşık iki milyon kişinin istihdam edildiği düşünüldüğünde sektörde çalışan bireylerin motivasyonlarının ya da verimlilik güdüsünün yüksek olması sektörün de genel verimliliğini arttıracağını söylemek mümkündür. Çalışanların örgütsel bağlılığının yüksek olması ise çalışanları daha uyumlu çalışmaya yönelterek daha üretken sonuçların ortaya çıkmasına neden olacaktır. Bireylerin daha yüksek sorumluluk ve sadakat duygusu içinde çalışmaları ise istihdamın maliyetini sektör bazında azaltacaktır. Bu nedenle çalışanların örgütsel bağllıklarını yüksek tutmak için çalışanların motivasyonları yükseltmek insan kaynaklarının önemli görevlerindendir. Bu durumdan hareketle bu çalışmada Türkiye'de perakende sektöründe öncü bir firmanın motivasyon araçlarının çalışanlarının örgütsel bağlılıkları ile ilişkisi incelenmektedir.

\section{Kuramsal çerçeve}

\section{Motivasyon araçları}

Kişiyi dıştan ve içten etkileyen güçlerle ilgili olan motivasyon, bireyin bir amaca yönelmesi ve harekete geçmesi anlamına gelmektedir. Motivasyon sürecinde önce kişinin davranışı tetiklenmekte ve kişi kendisine birtakım hedefler belirlemektedir. Sonrasında ise kişi amaca yönelik davranışlarda bulunmaktadır. Sürecin sonunda ise kişi hedefine ulaşarak gereksinimleri sağlamış olmaktadır (Torun, 2013). Bu açıdan bakıldığında motivasyonu genel anlamda dört özelliği ile tanımlanmak mümkündür. Birincisi motivasyonun kişisel bir olgu olduğu bu nedenle her insandan insana farklılık göstereceği ve tüm motivasyon teorilerinin temelinde bu farklılı̆̆ vurgulamak olduğudur. İkincisi motivasyonun genel olarak bir niyet olarak görülmesi ve motivasyonun çalışanların kontrolü altında olduğunun varsayılmasıdır. Üçüncüsü ise motivasyonun çok yönlü olduğudur. Burada neyin insanları aktif hale getireceğinin bilinmesi gerekmektedir. Dördüncüsü ise motivasyonun bir performans ve davranış olmadığı yönündedir (Genç, 2004). Başka bir motivasyon tanımı olarak ise Batmaz (2002), motivasyonun genellikle amaca yönelik davranışlarla alakalı bir süreç olduğunu belirtmiştir.

Motivasyonun anlaşılmasına yardımcı olan teoriler iki ayrı grupta incelenmektedir. Bunlardan birincisi kapsam teorileri, ikincisi ise süreç teorileridir. Kapsam teorileri motivasyonun bireyin kendisinde, bireyin davranışlarını tetikleyen ve sürdüren kavramlar olduğunu belirtirken, süreç teorileri ise bu davranışın nasıl tetiklendiğini, yönlendirildiğini ve sürdürüldüğüne anlam getirmeye çalışmaktadır (Sabuncuoğlu ve Tüz, 1998). Kapsam teorilerinin en bilinenleri Maslow 'un ihtiyaçlar hiyerarşisi, Alderfer'in (1969) ERG Teorisi, Herzberg'in (1993) Çift Faktör Teorisi ve Mcclelland'in (1961) Öğrenilebilen İhtiyaçlar Teorisi yaklaşımlarıdır. Süreç teorilerinin başlıcaları ise Beklenti Teorisi, Eşitlik Teorisi ve Amaç Teorisidir (Steers vd. 2004). Bu kapsamda süreç teorilerine göre ihtiyaçlar insanı davranışa yönelten bir unsur olarak görülmektedir.

Motive edici faktörler ve hijyen faktörlerini esas alan Herzberg' in Çift Faktör Teorisi ise kapsam teorileri çerçevesinde yer almıştır (Luthans, 2011). Herzberg'in çift faktör teorisi ile Maslow'un kuramını geliştirmiş ve deney yaparak bu kuramın geçerliliğini sorgulamıştır (Eren, 1997). Herzberg deneye katılanların iki soruya verdiği cevabı değerlendirerek kişilerin örgüt içindeki davranışlarını etkileyen faktörleri, iki ana faktör kümesinde incelemiş ve faktör kümelerini hijyen faktörleri ve motive edici faktörler olarak ayırmışlardır (Herzberg vd., 1993). Bu teoriye göre hijyen faktörleri olmazsa tatminsizlik oluşur, motive edici faktörler olursa tatmin doğmaktadır (Çöğür, 2010). Herzberg'e göre işin kendisi, başarma, gelişme olanakları, tanınma ve sorumluluk gibi motivasyon faktörleri bireyin güçlü bir şekilde motive olmasını sağlamaktadır. Bununla birlikte; ücret bilgisi, çalışma şartları, kurum imajı, çalışan-yönetici ilişkileri ve iş güvenliği gibi hijyen faktörlerinin yokluğu tatminsizliğe neden olmaktadır (Kondalkar, 2007). Bununla birlikte hijyen faktörleri, iş tatminsizliğini ortadan kaldırmaya yardımcı olmada asgari şartları sağlayan dişsal bileşenlerken; motivatörler iş tatminini sağlayan içsel unsurlar olarak görülmektedir (Steers vd., 2004; Brislin vd. 2005). 
Motivasyonu artırmak için kullanılan araçlar ekonomik, psikolojik-sosyal ve örgütsel-yönetsel (Barles, 2016) veya içsel ve dişsal olarak ifade edilmektedir (Allen ve Killman 2001). Bu çalışmada da motivasyon araçları içsel ve dışsal olarak Herzberg'in motivasyona bakış açısı kapsamında ele alınmıştır. Doğrudan işin yapılmasıyla ilgili olan faktörler içsel ödüllerdir (Mottaz, 1985). İçsel ödüller, kişinin yerine getirdiği işten doğal ve içten bir şekilde tatmin olmasını sağlamaktadır (Ryan ve Deci, 2000). Dişsal ödüller (Mottaz, 1985) ise örgüt tarafından yönlendirilen ve çalışanın denetimi dışındaki unsurlardan oluşmaktadır (Stumpf vd. 2013). Bir örgütte çalışanın başarısının, yetenekleri ile çalışma isteğinin çarpımına eşit olduğu belirtilmektedir. Çalışma isteğinin olmaması yetenekler çok iyi olsa bile bu durumda başarı sağlanmayacağını göstermektedir. Bu nedenle çalışan seçilirken öncelikle çalışanın sahip olduğu deneyim ve yeteneklerinin, iş gerekleri ve tanımları ile uyumlu olmasına özen gösterilmektedir. Nitekim seçilen çalışan her ne kadar yetenekli olursa olsun, çalışma isteği eksikse örgüte herhangi bir katkı sağlaması söz konusu değildir. Bu nedenle bir çalışanı örgüte aldıktan sonra yapılacak en önemli işlerden biri onu verimli çalışmaya isteklendirmektir. (Yüksel, 2000; Torun, 2013).

\section{Örgütsel bağlılık}

Örgütlerin ayakta kalması, çalışanların örgüt uğruna bilgi ve becerilerini kullanmalarıyla yakından ilgilidir. Nitekim, çalışanların işlerini yapma çabaları ve becerileri örgütlerin ayakta kalması için yeterli değildir. Örgütlerin güçlendirilmesi ve daha sonra büyümesi, çalışanların organizasyona karşı güçlü duygularına bağlı olmaktadır. Bunu başarmak için, işin gerektirdiği bilgi ve becerilere ek olarak, işçilerin iş ve çalışma ortamına karşı pozitif tutumları olmalıdır. Örgütün güç derecesi, çalışanların örgütlenmeye karşı olumlu tutum derecesine bağlıdır. Bu bağlamda örgütsel bağlılık kavramının örgütler için çok önemli olduğunu söylemek mümkündür (Bolat ve Bolat, 2008). Salanick'in yaklaşımına göre bağlılık, bireyin kendi davranışına bağlılığı olarak tanımlanmaktadır. Buna göre, bireyin bir örgüte olan bağlılığı konusunda karar verirken, bireyin inanç ve davranışlarına bağlılığı önemli olmaktadır (Uygur, 2004). Başka bir deyişle, bir bireyin tutum ve davranışları uyumlu olmadığında, birey gerginlik ve stres hissedecektir. Tutum ve davranışlar arasında uyumluluk bağlılık getirecektir (İnce ve Gül, 2005). Becker'den farklı olarak Salannick, tutarlı davranışların altında yatan nedenin bireyin tutum ve inançları olduğunu savunmaktadır (Gülova ve Demirsoy, 2012).

Örgütsel bağlılık kavramı ilk olarak 1956 yılında Whyte tarafından incelenmiş ve Mowday, Steers, Allen, Meyer ve Becker ve özellikle Porter gibi birçok araştırmacı tarafından geliştirilmiştir (Zorlu, 2019). Mowday, Steers ve Porter tarafından ilk kez açıklandığı gibi, örgütsel bağlılık, işçinin organizasyonuna duygusal olarak bağlı olması olarak tanımlanmıştır. Ayrıca hissedilen bağlılık derecesinin değerlerin benimsenme derecesine eşdeğer olduğu ileri sürülmüştür. Diğer çalışmalarda, örgütsel bağlılık, çalışanların örgütlerine yaptıkları yatırımların sonucu olarak gelişen bağlılık olarak tanımlanmıştır (Becker, 1960). Literatürde çok sık benimsenip araştırmaların yapıldığı sınıflandırma Meyer ve Allen (1991) tarafından geliştirilen örgütsel bağlılık sınıflandırmasıdır. Meyer ve Allen (1984) bu iki farklı örgütsel bağlılığı içeren bir model önermiş ve birincisini “duygusal bağlılık" ve ikincisini "devam bağlılık" olarak tanımlamışlardır. Bu modele Weiner ve Vardi (1980) tarafından önerilen ve Weiner (1982) tarafından geliştirilen "normatif" veya "etik" bağlılık boyutu eklenerek üç boyutlu örgütsel bağlılık modelini geliştirmişlerdir. Normatif bağlılık, çalışanın örgüte bağlılığı bir görev olarak gösterme algısının ve çalışanın örgütsel bağlılı̆̆ın "doğru" olduğu fikrinin bir sonucu olduğundan diğer iki türden bağlılığın ayrı bir boyutu temsil etmektedir (Wasti, 2003). Bu çalışmada da bu doğrultuda duygusal bağlılık, devamlılık bağlılığı ve normatif bağlılık olarak Meyer ve Allen örgütsel bağlılık boyutları ele alınmıştır.

\section{Literatür taraması}

Motivasyon araçları ve örgütsel bağlılık ilişkisini inceleyen çalışmalar mevcut olmakla birlikte, bu iki kavramın ilişkili olduğu yerli ve yabancı literatürde yapılmış birçok çalışmayla ortaya konmuştur. Bu doğrultuda yapılan çalışmalardan bazıları ve sonuçları incelendiğinde; Bilge ve arkadaşları (2015) içseldışsal motivasyon ile örgütsel bağlılık arasındaki ilişkiyi araştırmışlardır. Analizler sonucunda dişsal motivasyon faktörlerinin, içsel motivasyon üzerinde pozitif bir etkiye sahip olduğu ve örgütsel bağlılığın alt faktörleri olan, devam bağlılığı, duygusal bağlılık ve normatif bağlılık üzerinde pozitif bir etkiye sahip olduğu, içsel motivasyonun ise örgütsel bağlılığın alt faktörleri olan devam bağl1lığı, normatif bağlılık ve duygusal bağlılık üzerinde negatif bir etkiye sahip olduğu sonucuna ulaşılmıştır.

Başka bir çalışmada Ertit (2019) motivasyon, kişilik özellikleri ve örgütsel bağlılık arasındaki ilişkileri incelemiştir. Çalışmanın sonucunda, kişilik alt boyutları ile motivasyon alt boyutları arasında anlamlı görülen diğer ilişkilerin belirgin şekilde düşük olduğu tespit edilmiştir. En kuvvetli ilişki ise normatif bağlılık ve uzlaşılabilirlik ve aynı zamanda içsel motivasyon ve sorumluluk algıları arasında olduğu tespit edilmiştir. Canbaba (2019) yaptığı çalışmanın sonucunda ise motivasyon ile örgütsel bağlılık 
arasında pozitif, yükseğe yakın düzeyde bir ilişki olduğunu tespit etmiştir. Motivasyonun, örgütsel bağlılık üzerinde anlamlı bir etkisinin olduğu ve motivasyonun örgütsel bağlılık düzeyini arttırdı̆̆ görülmektedir. Araştırma sonucunda iş görenlerin motivasyonlarının ve örgütsel bağlılıklarının yüksek; motivasyonları ile örgütsel bağlılıkları arasındaki ilişkinin ise pozitif yönde olduğu sonucuna ulaşılmıştır.

Motivasyon araçları ve örgütsel bağlılık ilişkisini demografik açıdan inceleyen çalışmalarda mevcuttur. Örneğin, Tulunay ve Buluç (2018) ise, ilköğretim öğretmenlerinin motivasyon ve örgütsel bağlılığını demografik değişkenler açısından incelemiştir. Çalışmanın sonucunda mesleki kıdeme ve öğrenim durumuna göre anlamlı farklılık görülmemiş, fakat motivasyonun içsel ve dişsal alt boyutunda cinsiyete göre anlamlı farklılık olduğu görülmüştür. Yaşa göre dişsal boyutunda anlamlı farklılık varken, içsel boyutunda ise yerleşim yerine göre anlamlı farklılık olduğu görülmüştür. Örgütsel bağlılığında ise, medeni duruma, cinsiyete, öğrenim durumuna, yaşa ve mesleki kıdeme göre anlamlı farklılık görülürken, okulun bulunduğu yerleşim birimine göre farklılık olmadığ1 tespit edilmiştir. Benzer şekilde, Sarıoğlu (2019) ise çalışan motivasyonunu artırma araçlarının örgütsel bağlilık üzerindeki etkilerini araştırmıştır. Yapılan araştırma sonucunda duygusal bağlılık ile yaş arasında pozitif yönlü bir ilişkinin olduğu, erkek çalışanların duygusal bağlılıkları kadınlara göre; kadın çalışanların ise devam bağlılıkları erkeklere göre daha fazla olduğu evlilerin bekârlara göre duygusal bağlılık düzeylerinin daha fazla olduğu tespit edilmiştir. Eğitim seviyesinin artması devam ve normatif bağlılıklarında artışa neden olurken duygusal bağlılıklarında ise azalışa neden olmuştur, ücret düzeyi düştükçe duygusal bağlılığın azaldığı ve devam bağlılığının arttığı, normatif bağlılığın ise bundan etkilenmediği sonucuna ulaşılmıştır ayrıca ücret düzeyi düşük olan bireylerin psiko-sosyal araçlar ile motive oldukları görülmüşsür. Akademisyenler üzerine yapılmış başka bir çalışmada akademisyenlerin dışsal motivasyonlarının içsel motivasyonlarından daha düşük olduğu, deneyimi daha az olan akademisyenlerin içsel ve dışsal motivasyonlarının diğer akademisyenlerden daha düşük olduğu, dışsal motivasyon üzerindeki en etkili örgütsel bağlığın duygusal bağlılık olduğu tespit edilmiştir (Saraçlı vd., 2014). Başka bir çalışmada Keskin (2019), sosyal güvenlik çalışanlarında motivasyonun örgütsel bağlılığa etkisini araştırmıştır. Çalışmada, motivasyon faktörleri ile çalışma süresi ve eğitim düzeyleri arasında anlamlı bir farklılık olduğu sonucuna ulaşılmıştır. Buna ek olarak demografik özellikler ile örgütsel bağlılık faktörleri arasında ise anlamlı bir farklılık olmadığı tespit edilmiştir.

Tüm bu çalışmalardan elde edilen bilgilere göre; örgütsel bağlılık ile motivasyon araçları ilişkisi farklı sektörlerde kişilik ve demografik özelliklere göre araştırılmış genel olarak motivasyonun örgütsel bağlılık ile ilişkisi incelenmiş ve bunun sonucunda iş görenlerin motivasyonları ile örgütsel bağlılıkları arasında pozitif yönlü bir ilişki olduğu sonucu ortaya çıkmıştır. Genel olarak yapılan araştırmalarda motivasyonu ve örgütsel bağlılığ1 yüksek kişilerin, çalıştığı örgütte daha fazla çaba göstermede istekli oldukları tespit edilmiştir. Örgütsel bağlılığın çalışanlar üzerinde medeni duruma, cinsiyete, öğrenim durumuna, yaşa ve mesleki kıdeme göre anlamlı farklılıkları görülürken, yerleşim birimine göre farklılık olmadığı tespit edilmiştir ayrıca deneyimi daha az olan çalışanların içsel ve dişsal motivasyonlarının diğer çalışanlardan daha düşük olduğu, dışsal motivasyon üzerindeki en etkili örgütsel bağlığın duygusal bağlılık olduğu tespit edilmiştir. Duygusal bağlılık ile yaş arasında pozitif yönlü bir ilişkinin olduğu, erkek çalışanların duygusal bağlılıkları kadınlara göre; kadın çalışanların ise devam bağlılıkları erkeklere göre daha fazla olduğu evlilerin bekârlara göre duygusal bağlılık düzeylerinin daha fazla olduğu tespit edilmiştir. Eğitim seviyesinin artması devam ve normatif bağlılıklarında artışa neden olurken duygusal bağlılıklarında ise azalışa neden olmuştur, ücret düzeyi düştükçe duygusal bağlılığın azaldığı ve devam bağlılığının arttığı, normatif bağlılığın ise bundan etkilenmediği sonucuna ulaşılmıştır ayrıca ücret düzeyi düşük olan bireylerin psiko-sosyal araçlar ile motive oldukları tespit edildiği sonuçlarına ulaşılmıştır.

\section{Metodoloji}

\section{Araştırma modeli ve hipotezler}

$\mathrm{Bu}$ açıklamalar doğrultusunda literatür taramasından da hareketle aşağıdaki araştırma modeli kurulmuş ve hipotezler geliştirilmiştir. 


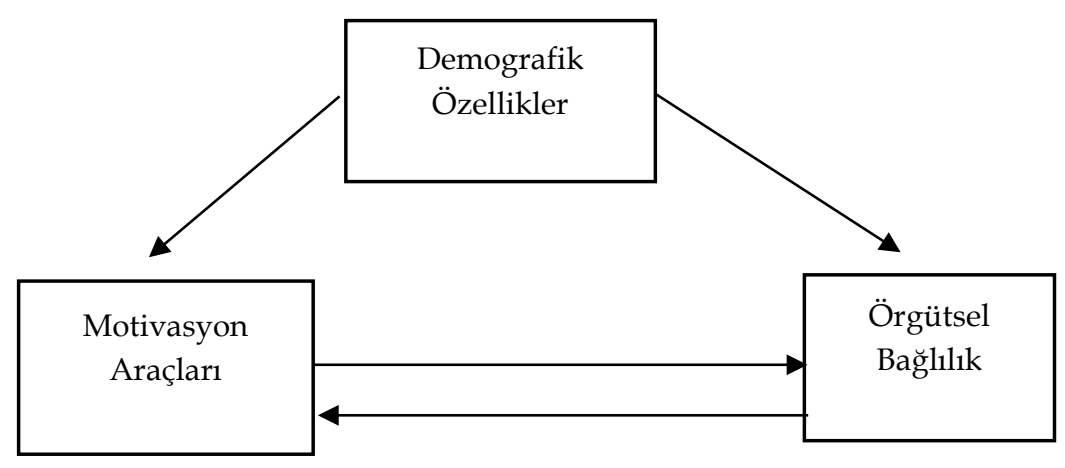

Şekil 1. Araştırmanın modeli

Bu modelden yola çıkılarak ise aşağıdaki hipotezler belirlenmiştir:

$\boldsymbol{H}_{1}$ : Motivasyon araçlan cinsiyete göre farklhlik göstermektedir.

$\mathrm{H}_{2}$ : Motivasyon araçlarn medeni durum göre farklılı göstermektedir.

$\mathrm{H}_{3}$ : Motivasyon araçları yaş grubuna göre farklllk göstermektedir.

$\boldsymbol{H}_{4}$ : Motivasyon araçlarn eğitim seviyesine göre farklllk göstermektedir.

$\boldsymbol{H}_{5}$ : Motivasyon araçları kurumda çalı̧̧ma süresine göre farklhlık göstermektedir.

$H_{6}$ : Motivasyon araçları kurumda unvana göre farklılık göstermektedir.

$H_{7}$ : Örgütsel bağhllik cinsiyete göre farklılık göstermektedir.

$\boldsymbol{H}_{8}$ : Örgütsel bağlllık medeni durum göre farkllllk göstermektedir.

$\mathbf{H}_{9}$ : Örgütsel bağhllik yaş grubuna göre farklllık göstermektedir.

$H_{10}$ : Örgütsel bağhllık eğitim seviyesine göre farklllık göstermektedir.

$H_{11}$ : Örgütsel bağlllık kurumda çalışma süresine göre farklllık göstermektedir.

H12: Örgütsel bağlllık kurumda unvana göre farklılık göstermektedir.

$H_{13}$ : Örgütsel bağlllık ve motivasyon araçları arasında ilişki vardır.

Bu hipotezlerin yanında ölçeklerin alt boyutlarına yönelik de farklılık ve ilişki analizleri incelenmiştir.

\section{Evren ve örneklem}

Çalışma kapsamında Türkiye ekonomisine önemli katkıları bulunan perakende sektörünün çalışanlarının motivasyon araçları ve örgütsel bağlılık düzeylerinin hangi düzeyde olduğunun, bu düzeylerin demografik özelliklere göre değişip değişmediğinin özellikle kuşaklar arası farklılık olup olmadığının ve motivasyon araçları ile örgütsel bağlılık arasındaki ilişkilerin incelenmesi amaçlanmıştır. Bu çalışma perakende sektörü özelinde olduğundan, bu çalışmanın doğrudan sektör bazında çalışan insan kaynakları yöneticilerine politika uygulamaları bakımından katkısının olacağı düşünülmektedir. Bu nedenle araştırma sonuçlarının bu yönde incelenmesi önemlidir. Araştırmanın verileri, Türkiye' de perakende sektörünün önde gelen firmalarından birinin çalışanlarına 2019 yılının Ocak-Nisan aylarını kapsayacak şekilde elektronik anket gönderilerek yapılmıştır. Kişilere anketin yer aldığı bağlantı toplu bir mail listesine elektronik posta yardımıyla gönderilmiş olup bu yolla çalışanlardan geri dönüş sağlanmıştır. Bu anlamda her çalışanın anketi yanıtlama olasılığı eşit oluğundan çalışmanın örneklemi basit rassal örneklemeye dayalı olarak oluşturulmuştur. Araştırmanın evrenini ise İstanbul'da perakende sektöründe çalışanlar oluşturmaktadır. Türkiye İstatistik Kurumu'nun (TUIK) 2016 yılında belirlediği istatistiğe göre Türkiye'de perakende sektöründe yaklaşık 1 milyon 810 bin kişi çalışmaktadır (KPMG, 2018). Türkiye' deki nüfusun yaklaşık \%18'inin İstanbul'da yaşadığı bilinmektedir. Bu nedenle ana kütle sayısı $325800\left(1810000^{*} 0,18\right)$ olarak elde edilmektedir. Bu çalışmada örneklem büyüklüğünün belirlenmesi için örneklem sayısı hesaplama formülünden $\left(n=\left(z^{2 *} p^{*}(1-p)\right) / d^{2}\right)$ yararlanılmıştır. Burada $n$ örneklem sayısını, $z$ normal dağılım tablosu değerini göstermektedir. $P$ ise ilgili olayın gerçekleşme olasılığıdır. Bu çalışmada bu değer kişinin ankete katılma olasılığı olarak, (1-p) ise seçilen kişinin ankete katılmama olasılığı olarak belirlenmiştir. Son olarak, $d$ ise belirlenen olasılıktaki hata payını göstermektedir. Olasılık tam bilinmediğinden bu değerin $(p) 0.50$ olduğu varsayılmıştır. $z$ değeri ise \% 95 güven düzeyinde normal dağılım tablosundan 1.96 olarak belirlenmiştir. Hata payını yüksek tutmak için bu hesaplamada hata payının $(d) \pm 0.10$ gibi bir rakam olduğu düşünülürse örneklem sayısı, örneklem sayısı hesaplama formülünden yaklaşık (n) 96 olarak 
elde edilmektedir. Bu rakama yönelik ( $\mathrm{n} / \mathrm{N}<0,05$ olduğundan) ana kütle düzeltme faktörüne gidilmemiştir. Nitekim, gerek ankette kullanılan ölçeklerin doğru ölçülmesi, gerek literatür taraması bölümünde bahsedilen çalışmalardan örnek alınarak bu araştırmada daha fazla kişiye ulaşılması amaçlanmış ve toplamda 216 çalışana ulaşılarak anket sonlandırılmıştır.

\section{Ölçekler}

Çalışmada veri toplamaya yönelik kullanılan anketin ilk bölümünde demografik bilgiler yer almaktadır. Çalışmanın ölçekleri ile ilgili olarak Meyer ve Allen (1991) tarafından geliştirilen örgütsel bağlılık ölçeği kullanılmıştır. Ölçeğin Türkçeye uyarlaması ise Wasti (2000) tarafından yapılmıştır. Ölçek toplamda 18 maddeden oluşmaktan olup 3 alt boyutu vardır. Ölçekteki 1-6 numaralı maddeler duygusal bağlılığı, 7-12 numaralı maddeler devam bağlılığını, 13-18 numaralı maddeler ise normatif bağllılı̆̆ ölçmektedir. Motivasyon araçlarının ölçümünde ise, Dündar vd. (2007) tarafından Mottaz (1985), Brislin vd. (2005), Mahaney ve Lederer (2006)'ın çalışmalarındaki temel ölçeklerden yararlanılarak oluşturulan motivasyon araçları ölçeği kullanılmıştır. Cronbach alfa katsayının 0,80 üzerinde elde edildiği ve ölçeğin güvenilir olduğu belirtildiği bu çalışmada motivasyon araçlarının içsel ve dışsal motivasyon araçları olmak üzere iki alt boyutta ele alındığını içsel motivasyon araçları ile ilgili 9 madde, dışsal motivasyon araçları ile ilgili 15 maddenin yer aldığı belirtilmiştir. Araştırmada öncelikle verilerin tanıtılması açısından tanımlayıcı istatistiklere (ortalama, standart sapma, frekans gibi) yer verilmiştir. Sonrasında ölçeklerin Cronbach alfa (a) güvenirlik değerleri hesaplanmıştır. Sonrasında ölçeklerin Cronbach alfa ( $\alpha$ ) güvenirlik değerleri hesaplanmıştır. Ayrıca ölçeklerin alt boyuta ayrılmaların teori ile uyup uymadığının kontrolü için doğrulayıcı faktör analizi yapılmıştır. Bu adımdan sonra ölçülen motivasyon araçları ve örgütsel bağlılık ölçeklerinin çalışanların demografik özelliklerine göre değişip değişmediği normallik testi sonuçlarına göre Anova (ya da Kruskal Wallis) ve t testi (ya da Mann Whitney testi) yardımlarıyla incelenmiştir. Son olarak örgütsel bağlılık ve motivasyon araçları ilişkisinin incelenmesi açısından regresyon/korelasyon analizinden yapılmıştır. Tüm bu analizler SPSS 22 ve AMOS 22 paket programlarında yapılmıştır.

\section{Bulgular}

Motivasyon araçları ile örgütsel bağlllık arasındaki ilişkinin incelendiği bu çalışmada öncelikle araştırmaya katılanların profili incelenmiş ve sonuçları Tablo 1'de gösterilmiştir.

Tablo 1: Katılımcıların Demografik Özelliklerinin Dağılımı (n=216)

\begin{tabular}{|c|c|c|c|}
\hline & & Frekans & $\%$ \\
\hline \multirow[t]{2}{*}{ Cinsiyet } & Kadın & 128 & 59,3 \\
\hline & Erkek & 88 & 40,7 \\
\hline \multirow[t]{2}{*}{ Medeni Durum } & Bekâr & 125 & 57,9 \\
\hline & Evli & 91 & 42,1 \\
\hline \multirow[t]{6}{*}{ Yaş Grubu } & $18-23$ & 12 & 5,6 \\
\hline & $24-29$ & 75 & 34,7 \\
\hline & $30-39$ & 93 & 43,1 \\
\hline & $40-49$ & 29 & 13,4 \\
\hline & $50-59$ & 6 & 2,8 \\
\hline & 60 ve üstü & 1 & 0,5 \\
\hline \multirow[t]{7}{*}{ Eğitim Seviyesi } & İlkokul & 3 & 1,4 \\
\hline & Ortaokul & 1 & 0,5 \\
\hline & Lise & 36 & 16,7 \\
\hline & Ön lisans & 30 & 13,9 \\
\hline & Lisans & 100 & 46,3 \\
\hline & Yüksek Lisans & 42 & 19,4 \\
\hline & Doktora & 4 & 1,9 \\
\hline \multirow{7}{*}{ Çalışma Süresi } & 2 yıldan az & 54 & 25,0 \\
\hline & $2-4$ yil & 62 & 28,7 \\
\hline & $5-7$ yil & 40 & 18,5 \\
\hline & $8-10$ y1l & 28 & 13,0 \\
\hline & $11-15$ y1l & 17 & 7,9 \\
\hline & $16-20 \mathrm{y} 1 \mathrm{l}$ & 8 & 3,7 \\
\hline & $21-29$ yil & 7 & 3,2 \\
\hline \multirow[t]{7}{*}{ Unvan } & İşçi & 53 & 24,5 \\
\hline & Memur & 32 & 14,8 \\
\hline & Asistan & 7 & 3,2 \\
\hline & Uzman Yardımcısı & 8 & 3,7 \\
\hline & Uzman & 62 & 28,7 \\
\hline & Müdür Yardımcısı & 22 & 10,2 \\
\hline & Müdür & 32 & 14,8 \\
\hline
\end{tabular}


Frekans tablosuna göre cinsiyet durumuna göre kadın katılımcılar erkeklerden daha fazla, medeni duruma göre bekâr katılımcılar evlilerden daha fazla, yaş grubuna göre 24-29 ve 30-39 yaş aralığındaki katılımcılar diğer yaş gruplarındaki katılımcılardan daha fazla, eğitim seviyesine göre lisans mezunu katılımcılar diğer eğitim seviyesindeki katılımcılardan daha fazla, çalışma süresine göre 2 yıldan az, 24 yıl ve 5-7 yıl arasında çalışan katılımcılar ve unvan olarak işçi, memur ve uzman olarak çalışan katılımcıların diğer katılımcılardan fazla sayıda olduğu görülmektedir.

Bu adımdan sonra çalışmada kullanılan motivasyon araçları ve örgütsel bağlılık ölçeklerinin güvenirlik analizi yapılmıştır. Buna göre örgütsel bağlllık için Cronbach alfa (a) değeri 0,85 iken, motivasyon araçları için 0,90 olarak elde edilmiştir. Kalaycı (2010) Cronbach alfa değeri $0.80 \leq a<1.00$ değerleri arasında ise yüksek güvenirliğe sahip olduğunu belirtmiştir. Bu nedenle her iki değer de 0,80'den yüksek olduğu için ölçeklerin iyi derecede güvenilir olduğu söylenebilir. Alt boyutlar içinse sırasıyla Cronbach alfa (a) değerleri ayrıca hesaplanmıştır. Örgütsel bağlllı̆̆ın alt ölçeklerinden olan duygusal bağlılık için Cronbach alfa ( () değeri 0,94, devam bağlllığ için 0,83, normatif bağllık için 0,71 olarak elde edilmişken motivasyon araçlarından içsel motivasyon araçları için 0.83 , dışsal motivasyon araçları için ise 0,85 olarak elde edilmiştir. Normatif bağlllık için güvenirliğin orta seviyede olduğu görülmektedir. Bu nedenle doğrulayıcı faktör analizi ile incelenmesinde yarar vardır. Bu ölçeklerin literatürde belirtilen şekilde alt boyutlarına doğru bir şekilde ayrılıp ayrılmadığının analizinin yapılması gerekmektedir. Bu nedenle AMOS 22 programında doğrulayıcı faktör analizi uygulanmıştır.

Tablo 2: Doğrulayıcı Faktör Analiz Soncunda Elde Edilen Madde Faktör Yükleri

\begin{tabular}{|l|l|l|l|}
\hline & & Maddeler & Faktör Yükleri \\
\hline OB6 & $<---$ & Duygusal_Bağlllık &, 868 \\
\hline OB5 & $<---$ & Duygusal_Bağlllık &, 879 \\
\hline OB4 & $<---$ & Duygusal_Bağlllık &, 874 \\
\hline OB3 & $<---$ & Duygusal_Bağlllık &, 921 \\
\hline OB2 & $<---$ & Duygusal_Bağlllık &, 810 \\
\hline OB1 & $<---$ & Duygusal_Bağlllık &, 737 \\
\hline OB12 & $<---$ & Devam_Baglllık &, 712 \\
\hline OB10 & $<---$ & Devam_Baglllık &, 877 \\
\hline OB9 & $<---$ & Devam_Baglıllk &, 692 \\
\hline OB8 & $<---$ & Devam_Baglllık &, 714 \\
\hline OB7 & $<---$ & Devam_Baglılık &, 603 \\
\hline OB18 & $<---$ & Normatif_Baglıllk &, 741 \\
\hline OB16 & $<---$ & Normatif_Baglıllk &, 893 \\
\hline MA1 & $<---$ & İcsel_Motivasyon &, 550 \\
\hline MA2 & $<---$ & İcsel_Motivasyon &, 578 \\
\hline MA3 & $<---$ & İcsel_Motivasyon &, 641 \\
\hline MA5 & $<---$ & İcsel_Motivasyon &, 749 \\
\hline MA6 & $<---$ & İcsel_Motivasyon &, 605 \\
\hline MA7 & $<---$ & İcsel_Motivasyon &, 535 \\
\hline MA8 & $<---$ & İcsel_Motivasyon &, 786 \\
\hline MA9 & $<---$ & İcsel_Motivasyon &, 524 \\
\hline MA13 & $<---$ & Dissal_Motivasyon &, 503 \\
\hline MA14 & $<---$ & Dissal_Motivasyon &, 608 \\
\hline MA15 & $<---$ & Dissal_Motivasyon &, 621 \\
\hline MA16 & $<---$ & Dissal_Motivasyon &, 585 \\
\hline MA17 & $<---$ & Dissal_Motivasyon &, 673 \\
\hline MA18 & $<---$ & Dissal_Motivasyon &, 710 \\
\hline MA19 & $<---$ & Dissal_Motivasyon &, 531 \\
\hline MA20 & $<---$ & Dissal_Motivasyon &, 615 \\
\hline MA21 & $<---$ & Dissal_Motivasyon &, 563 \\
\hline MA24 & $<---$ & Dissal_Motivasyon &, 533 \\
\hline
\end{tabular}

Doğrulayıcı faktör analizi için ilk analiz yapıldığında standardize faktör yükü 0.50 'nin altında olan maddelerin olduğu görülmüştür. Bu durumda bu maddeler analizden dışlanarak tekrar doğrulayıcı faktör analizi yapılıp ilgili kovaryanslar da gösterildikten sonra uyum iyiliği bakımından uygun bir model elde edilmiş ve sonuçları Şekil 2'de gösterilmiştir. Şekil 2 incelendiğinde örgütsel bağlllıktan 5 adet maddenin dışlandığı, motivasyon araçlarından ise 6 adet maddenin dışlandığı görülmüştür. Analiz sonucunda $\mathrm{cmin} / \mathrm{df}=1,90, \mathrm{GFI}=0,82, \mathrm{RMR}=0,06, \mathrm{CFI}=0,90$, RMSEA $=0,06$ olarak elde edilmiştir. Hair vd. (2010) bahsettiği kabul edilebilir uyum iyiliği değerleri ile bu değerler karşılaştırıldığında GFI değeri haricinde diğer değerlerin iyi ya da kabul edilebilir uyum iyiliği derecesinde olduğu söylenebilir. 
Analiz sonunda örgütsel bağlılık ölçeğinden $11,13,14,15$ ve 17 numaralı maddeler, motivasyon araçları ölçeğinden ise 4, 10, 11, 12, 22 ve 23 numaralı maddeler dışlanmıştır. Doğrulayıcı faktör analiz soncunda elde edilen madde faktör yükleri Tablo 2 ' de gösterilmiştir.

İlgili maddelerin analiz dışı bırakıldıktan sonra tekrardan Cronbach alfa ( $\alpha$ ) değerleri hesaplanmıştır. Cronbach alfa (a) değeri örgütsel bağlllık ölçeği için 0,82 olarak, motivasyon araçları içinse 0,90 olarak elde edildiğinden güvenirlik hala iyi düzeydir. Alt boyutlar için tekrar incelendiğinde ise Cronbach alfa (a) değerleri örgütsel bağlllık ölçeğinde duygusal bağlllık için 0,94 , devam bağlılı̆̆ için 0,85 , normatif bağlılık için 0,80; motivasyon araçları ölçeğinde ise içsel motivasyon araçları için 0,83 , dışsal motivasyon araçları için 0,86 olarak elde edilmiştir. Alt boyutların güvenirliklerindeki yükselme nedeniyle bu çalışmada ilgili maddelerin çıkarılıp analize bu şekilde devam edilmesi uygun görülmüştür.

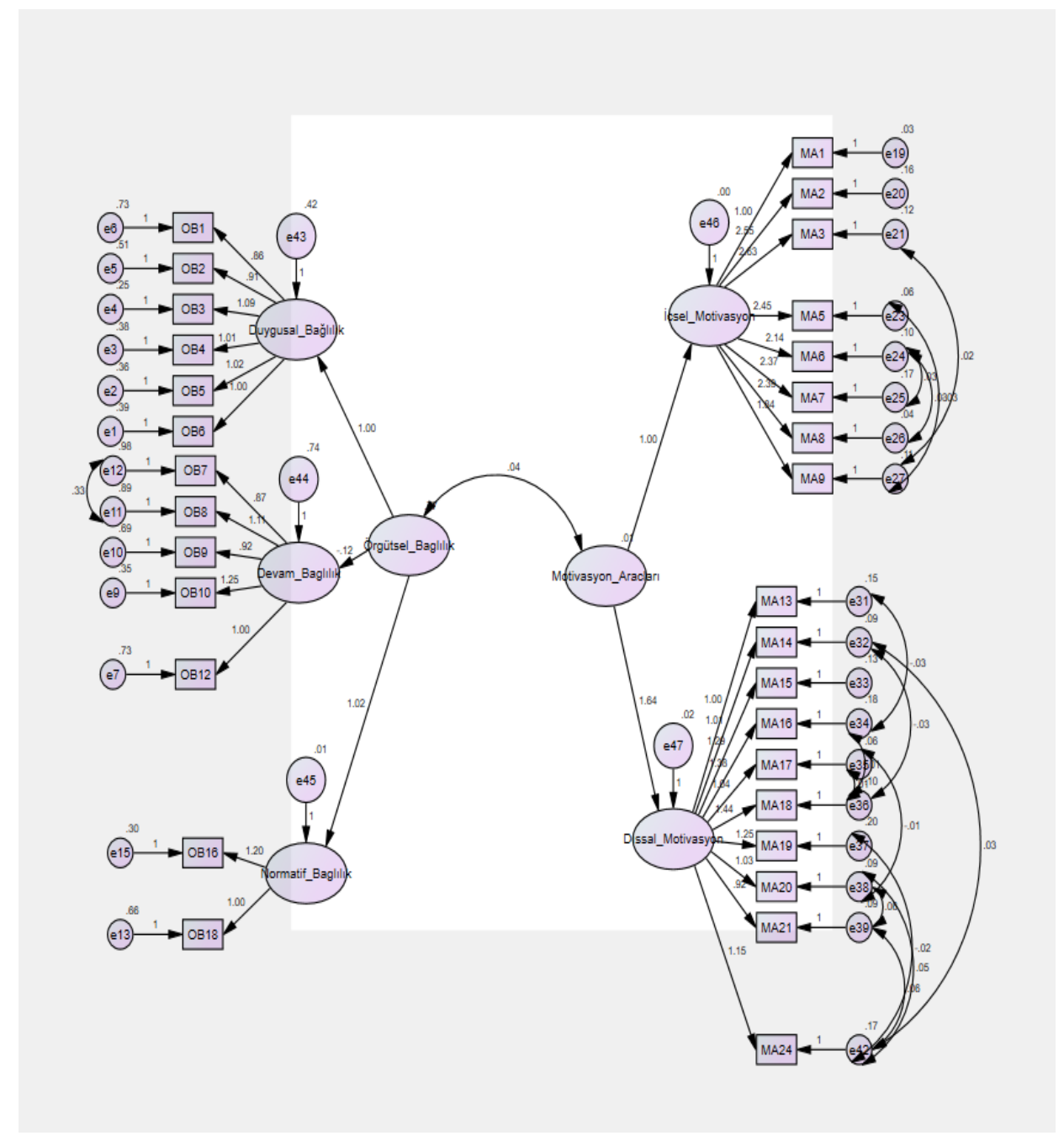

Şekil 2. Doğrulayıcı Faktör Analizi Çıktısı

$\mathrm{Bu}$ adımdan sonra her bir ölçek ve alt boyut için maddelerin ortalamaları ${ }^{1}$ alınarak puanlar hesaplanmıştır. Buradan yola çıkılarak Tablo 3 'te örgütsel bağllık ölçeğine yönelik tanımlayıcı istatistikler sunulmuştur.

\footnotetext{
${ }^{1}$ Çalışmalarda genelde ya ortalamalarla ya da faktör skorları ile devam edildiği bilinmektedir. Bu çalışmada sonuçların kontrol edilmesi açısından faktör skorları da kaydedilmiş ve analizler tekrarlanmıştır. Bu analizler sonucunda benzer sonuçlar elde edildiğinden burada sonuçlar ayrıca sunulmamıştır.
} 
Tablo 3: Çalışanların Örgütsel Bağlılık ve Motivasyon Araçları Ölçeklerine Yönelik Tanımlayıcı İstatistikler $(\mathrm{n}=216)$

\begin{tabular}{|l|l|l|l|l|}
\hline & Ortalama & Standart Sapma & Minimum & Maximum \\
\hline Örgütsel Bağlılık & 3,1 & 0,7 & 1,2 & 5,0 \\
\hline Duygusal Bağllıı & 3,4 & 1,1 & 1,0 & 5,0 \\
\hline Devam Bağlılık & 2,7 & 1,0 & 1,0 & 5,0 \\
\hline Normatif Bağlılık & 3,2 & 1,1 & 1,0 & 5,0 \\
\hline Motivasyon Araçları & 2,9 & 0,3 & 1,0 & 3,0 \\
\hline İçsel Motivasyon Araçları & 2,9 & 0,3 & 1,0 & 3,0 \\
\hline Dişsal Motivasyon Araçları & 2,8 & 0,3 & 1,0 & 3,0 \\
\hline
\end{tabular}

Tablo 3'teki tanımlayıcı istatistikler incelendiğinde çalışanların örgütsel bağlllık ölçeğinden duygusal bağllılı puanlarının devam bağllığı ve normatif bağlılık puanlarından daha yüksek olduğu görülmüştür. Motivasyon araçları ölçeğinden ise içsel ve dışsal motivasyon araçlarının puanlarının birbirine yakın olduğu görülmekte ve bu değerlerin 3'e yakın olduğu gözlemlenmiştir. Buradan çalışanların genellikle maddelere "motive eder" şeklinde yanıt verdiği sonucu çıarılabilir.

$\mathrm{Bu}$ adımdan sonra puanların gruplar arasında farklılıklarının analizine geçmeden önce normallik analizi yapılmış ve sonuçları Tablo 4 'te verilmiştir. Tablo 4 'te verilen sonuçlara göre \%95 güven düzeyinde hem Kolmogorov-Smirnov hem de Shapiro-Wilk testleri (Razali \& Wah, 2011) için verilerin dağılımın normale uygun olduğunu belirten hipotez reddedilmiştir $(\mathrm{p}<0,05)$. Bu nedenle tüm değişkenlerin normal dağılıma uymadığı görülmektedir. Farklılık analizlerinde parametrik testler yerine parametrik olmayan testlerin yapılması daha uygun olacaktır.

Tablo 4: Normallik Testleri

\begin{tabular}{|l|l|l|l|l|l|l|}
\hline & $\begin{array}{l}\text { Kolmogorov- } \\
\text { Smirnov }\end{array}$ & $\begin{array}{l}\text { Serbestlik } \\
\text { Derecesi }\end{array}$ & $\boldsymbol{p}$ & $\begin{array}{l}\text { Shapiro- } \\
\text { Wilk }\end{array}$ & $\begin{array}{l}\text { Serbestlik } \\
\text { Derecesi }\end{array}$ & $\boldsymbol{P}$ \\
\hline Örgütsel Bağlılık & 0,1 & 216,0 & 0,00 & 1,0 & 216,0 & 0,00 \\
\hline Duygusal Bağlllık & 0,1 & 216,0 & 0,00 & 0,9 & 216,0 & 0,00 \\
\hline Devam Bağlllık & 0,1 & 216,0 & 0,00 & 1,0 & 216,0 & 0,00 \\
\hline Normatif Bağllılk & 0,1 & 216,0 & 0,00 & 1,0 & 216,0 & 0,00 \\
\hline Motivasyon Araçları & 0,3 & 216,0 & 0,00 & 0,6 & 216,0 & 0,00 \\
\hline İçsel Motivasyon Araçları & 0,4 & 216,0 & 0,00 & 0,5 & 216,0 & 0,00 \\
\hline Dişsal Motivasyon Araçları & 0,3 & 216,0 & 0,00 & 0,6 & 216,0 & 0,00 \\
\hline
\end{tabular}

Tablo 5 ve Tablo 6'da ise motivasyon araçları ölçeğinin ve alt boyutlarının içsel ve dışsal motivasyon araçlarının değerlerinin çalışanların demografik özelliklerine göre farklılaşıp farklılaşmadığının analizine yer verilmiştir. Cinsiyet ve medeni duruma göre farklılaşmanın olup olmadığı bağımsız örneklem Mann Whitney U testi ile çalışanların yaş grubu, eğitim seviyesi, çalışma süresi ve unvana göre farklılaşmanın olup olmadığı ise Kruskal Wallis testi ile test edilmiştir.

Tablo 5: Çalışanların Demografik Özelliklerine Cinsiyete, Medeni Duruma ve Yaşa Göre Motivasyon Araçları Ölçeği Puan Ortalamalarının Dağılımı ( $(n=216)$

\begin{tabular}{|c|c|c|c|c|c|c|c|c|c|c|c|c|c|}
\hline & & \multicolumn{4}{|c|}{ Motivasyon Araçları } & \multicolumn{4}{|c|}{ İçsel Motivasyon Araçları } & \multicolumn{4}{|c|}{ Dişsal Motivasyon Araçları } \\
\hline & $\mathrm{n}$ & Ort & SS & Test & $p$ & Ort & SS & Test & $p$ & Ort & SS & Test & $P$ \\
\hline \multicolumn{14}{|l|}{ Cinsiyet } \\
\hline Kadın & 128 & 2,9 & 0,2 & \multirow{2}{*}{4152,5} & \multirow{2}{*}{0,00} & 2,9 & 0,2 & \multirow{2}{*}{4590,5} & \multirow{2}{*}{0,01} & 2,9 & 0,3 & \multirow{2}{*}{4506,5} & \multirow{2}{*}{0,01} \\
\hline Erkek & 88 & 2,8 & 0,3 & & & 2,8 & 0,3 & & & 2,8 & 0,3 & & \\
\hline \multicolumn{14}{|c|}{ Medeni Durum } \\
\hline Bekâr & 125 & 2,8 & 0,3 & \multirow{2}{*}{5384,5} & \multirow{2}{*}{0,48} & 2,9 & 0,3 & \multirow{2}{*}{4853,5} & \multirow{2}{*}{0,03} & 2,8 & 0,3 & \multirow{2}{*}{5638,0} & \multirow{2}{*}{0,90} \\
\hline Evli & 91 & 2,9 & 0,2 & & & 2,9 & 0,2 & & & 2,8 & 0,2 & & \\
\hline \multicolumn{14}{|l|}{ Yaş } \\
\hline $18-23$ & 12 & 3,0 & 0,0 & \multirow{6}{*}{18,8} & \multirow{6}{*}{0,00} & 3,0 & 0,0 & \multirow{6}{*}{7,5} & \multirow{6}{*}{0,19} & 3,0 & 0,0 & \multirow{6}{*}{17,5} & \multirow{6}{*}{0,00} \\
\hline $24-29$ & 75 & 2,8 & 0,2 & & & 2,8 & 0,3 & & & 2,8 & 0,2 & & \\
\hline 30-39 & 93 & 2,9 & 0,2 & & & 2,9 & 0,2 & & & 2,8 & 0,3 & & \\
\hline $40-49$ & 29 & 2,8 & 0,4 & & & 2,9 & 0,4 & & & 2,8 & 0,4 & & \\
\hline $50-59$ & 6 & 3,0 & 0,0 & & & 3,0 & 0,1 & & & 3,0 & 0,0 & & \\
\hline 60 ve üstü & 1 & 3,0 & 0,0 & & & 3,0 & 0,0 & & & 3,0 & 0,0 & & \\
\hline
\end{tabular}


Tablo 5 incelendiğinde cinsiyete göre motivasyon araçları, içsel ve dışsal motivasyon araçlarının puanlarının farklılaştığı görülmektedir $(\mathrm{p}<0,05)$. Gruplar arası fark için ayrı ayrı Mann Whitney U testi yapılmıştır. Bu test sonuçlarına göre kadınlarda bu puanların daha yüksek olduğu gözlemlenmiştir. Medeni duruma göre ise motivasyon araçları ve dışsal motivasyon araçlarının farklılaşmadığ $(p \geq 0,05)$ görülmüş̧tür. İçsel motivasyon araçlarının ise medeni duruma göre farklılaştığı görülmüştür $(p<0,05)$. Evlilerde içsel motivasyonun daha yüksek olduğu görülmüştür. Yaş gruplarına göre motivasyon araçlarının ve dişsal motivasyon araçlarının farklılaştı̆̆ sonucuna ulaşılmış $(\mathrm{p}<0,05)$ içsel motivasyon araçlarının ise değişmediği gözlemlenmiştir ( $\mathrm{p} \geq 0,05)$. Test sonuçlarına göre 18-23 yaş grubundakilerin 24-19 yaş grubundakilerden ve 30-39 yaş grubundakilerden yüksek; 50-59 yaş grubundakilerin 24-29 ve 30-39 yaş grubundakilerinden motivasyon ve dışsal motivasyon araçları puanlarının daha yüksek olduğu gözlemlenmiştir.

Tablo 6: Çalışanların Demografik Özelliklerinden Eğitim Seviyesi, Kurumda Çalışma Süresi, Unvana Göre Motivasyon Araçları Ölçeği Puan Ortalamalarının Dağılımı- (n=216)

\begin{tabular}{|c|c|c|c|c|c|c|c|c|c|c|c|c|c|}
\hline & & \multicolumn{4}{|c|}{ Motivasyon Araçları } & \multicolumn{4}{|c|}{ İçsel Motivasyon Araçları } & \multicolumn{4}{|c|}{ Dışsal Motivasyon Araçları } \\
\hline & $\mathrm{n}$ & Ort & SS & Test & $p$ & Ort & SS & Test & $p$ & Ort & SS & Test & $P$ \\
\hline \multicolumn{14}{|l|}{ Eğitim Seviyesi } \\
\hline İlkokul & 3 & 2,9 & 0,1 & \multirow{7}{*}{3,6} & \multirow{7}{*}{0,73} & 3,0 & 0,1 & \multirow{7}{*}{4,5} & \multirow{7}{*}{0,61} & 2,9 & 0,1 & \multirow{7}{*}{4,2} & \multirow{7}{*}{0,64} \\
\hline Ortaokul & 1 & 2,9 & 0,0 & & & 3,0 & 0,0 & & & 2,9 & 0,0 & & \\
\hline Lise & 36 & 2,9 & 0,1 & & & 2,9 & 0,2 & & & 2,9 & 0,1 & & \\
\hline Ön lisans & 30 & 2,8 & 0,3 & & & 2,8 & 0,4 & & & 2,8 & 0,3 & & \\
\hline Lisans & 100 & 2,9 & 0,3 & & & 2,9 & 0,3 & & & 2,8 & 0,3 & & \\
\hline Yüksek Lisans & 42 & 2,8 & 0,3 & & & 2,8 & 0,3 & & & 2,8 & 0,3 & & \\
\hline Doktora & 4 & 2,8 & 0,1 & & & 3,0 & 0,1 & & & 2,8 & 0,1 & & \\
\hline \multicolumn{14}{|c|}{ Kurumda Çalışma Süresi } \\
\hline 2 yıldan az & 54 & 2,9 & 0,2 & \multirow{8}{*}{3,7} & \multirow{8}{*}{0,72} & 2,9 & 0,3 & \multirow{8}{*}{5,7} & \multirow{8}{*}{0,46} & 2,9 & 0,2 & \multirow{8}{*}{6,0} & \multirow{8}{*}{0,43} \\
\hline $2-4$ yil & 62 & 2,9 & 0,2 & & & 2,9 & 0,3 & & & 2,9 & 0,2 & & \\
\hline $5-7$ yil & 40 & 2,9 & 0,2 & & & 2,9 & 0,2 & & & 2,8 & 0,2 & & \\
\hline $8-10$ yil & 28 & 2,9 & 0,3 & & & 2,9 & 0,2 & & & 2,8 & 0,4 & & \\
\hline $11-15$ yil & 17 & 2,9 & 0,1 & & & 3,0 & 0,0 & & & 2,8 & 0,2 & & \\
\hline $16-20 \mathrm{y} 1 \mathrm{l}$ & 8 & 2,9 & 0,2 & & & 2,9 & 0,2 & & & 2,9 & 0,2 & & \\
\hline 21-29 y1l & 7 & 2,7 & 0,7 & & & 2,7 & 0,8 & & & 2,7 & 0,7 & & \\
\hline 30 ve üstü & 0 & 0,0 & 0,0 & & & 0,0 & 0,0 & & & 0,0 & 0,0 & & \\
\hline \multicolumn{14}{|l|}{ Unvan } \\
\hline İşçi & 53 & 2,8 & 0,3 & \multirow{8}{*}{6,6} & \multirow{8}{*}{0,36} & 2,8 & 0,3 & \multirow{8}{*}{4,4} & \multirow{8}{*}{0,63} & 2,9 & 0,2 & \multirow{8}{*}{8,2} & \multirow{8}{*}{0,22} \\
\hline Memur & 32 & 2,8 & 0,2 & & & 2,9 & 0,2 & & & 2,8 & 0,2 & & \\
\hline Asistan & 7 & 2,9 & 0,2 & & & 2,9 & 0,2 & & & 2,9 & 0,2 & & \\
\hline Uzman Yardımcisı & 8 & 2,8 & 0,3 & & & 2,8 & 0,3 & & & 2,8 & 0,3 & & \\
\hline Uzman & 62 & 2,9 & 0,2 & & & 2,9 & 0,2 & & & 2,8 & 0,3 & & \\
\hline Müdür Yardımcısı & 22 & 2,9 & 0,1 & & & 2,9 & 0,2 & & & 2,9 & 0,1 & & \\
\hline Müdür & 32 & 2,9 & 0,4 & & & 2,9 & 0,4 & & & 2,8 & 0,4 & & \\
\hline Diğer & 0 & 0,0 & 0,0 & & & 0,0 & 0,0 & & & 0,0 & 0,0 & & \\
\hline
\end{tabular}

Tablo 6'daki demografik özellikler incelendiğinde eğitim seviyesi olarak, kurumda çalışma süresi ve unvana göre ise motivasyon araçları ve alt boyutları olan içsel ve dişsal motivasyon araçlarının ortalamaları arasında fark bulunmamıştır. Bu sonuçlara göre $\mathrm{H}_{1}, \mathrm{H}_{2}$ ve $\mathrm{H}_{3}$ hipotezlerinin desteklendiği, $\mathrm{H}_{4}, \mathrm{H}_{5}, \mathrm{H}_{6}$ hipotezlerinin ise desteklenmediği söylenebilir.

Tablo 7' de ise örgütsel bağlllık ve alt boyutları olan duygusal bağlılık, devam bağlılı̆̆ı, normatif bağlllık değerlerinin demografik özelliklerine göre farklılaşıp farklılaşmadığının analizine yer verilmiştir. Yine cinsiyet ve medeni duruma göre farklılaşmanın olup olmadığı bağımsız örneklem Mann Whitney U testi ile, çalışanların yaş grubu, eğitim seviyesi, çalışma süresi ve unvana göre farklılaşmanın olup olmadığı ise Kruskal Wallis testi ile test edilmiştir. 
Tablo 7: Çalışanların Demografik Özelliklerine Göre Örgütsel Bağlllık Ölçeği Puan Ortalamalarının Dağılımı (n=216)

\begin{tabular}{|c|c|c|c|c|c|c|c|c|c|c|c|c|c|c|c|c|c|}
\hline & \multirow[b]{2}{*}{$\mathrm{n}$} & \multicolumn{4}{|c|}{ Örgütsel Bağlılık } & \multicolumn{4}{|c|}{ Duygusal Bağlılık } & \multicolumn{4}{|c|}{ Devam Bağlılık } & \multicolumn{4}{|c|}{ Normatif Bağlılık } \\
\hline & & Ort & SS & Test & $p$ & Ort & SS & Test & $p$ & Ort & SS & Test & $p$ & Ort & SS & Test & $p$ \\
\hline \multicolumn{18}{|l|}{ Cinsiyet } \\
\hline Kadın & 128 & 3,1 & 0,7 & \multirow{2}{*}{$\begin{array}{l}5495 \\
, 5\end{array}$} & \multirow{2}{*}{0,76} & 3,5 & 1,0 & \multirow{2}{*}{$\begin{array}{l}5522 \\
, 0\end{array}$} & \multirow{2}{*}{$\begin{array}{l}0,8 \\
1\end{array}$} & 2,6 & 1,0 & \multirow{2}{*}{$\begin{array}{l}5124 \\
, 0\end{array}$} & \multirow{2}{*}{$\begin{array}{l}0,2 \\
6\end{array}$} & 3,2 & 1,1 & \multirow{2}{*}{$\begin{array}{l}5622 \\
5\end{array}$} & \multirow{2}{*}{0,98} \\
\hline Erkek & 88 & 3,1 & 0,7 & & & 3,4 & 1,2 & & & 2,8 & 1,0 & & & 3,1 & 1,2 & & \\
\hline \multicolumn{18}{|l|}{ Medeni Durum } \\
\hline Bekâr & 125 & 3,0 & 0,8 & \multirow{2}{*}{$\begin{array}{l}5181 \\
, 5\end{array}$} & \multirow{2}{*}{0,26} & 3,3 & 1,1 & \multirow{2}{*}{$\begin{array}{l}4801 \\
5\end{array}$} & \multirow{2}{*}{$\begin{array}{l}0,0 \\
5\end{array}$} & 2,7 & 1,0 & \multirow{2}{*}{$\begin{array}{l}5595 \\
, 5\end{array}$} & \multirow{2}{*}{$\begin{array}{l}0,8 \\
4\end{array}$} & 3,1 & 1,1 & \multirow{2}{*}{$\begin{array}{l}5444 \\
, 5\end{array}$} & \multirow{2}{*}{0,59} \\
\hline Evli & 91 & 3,2 & 0,6 & & & 3,6 & 1,0 & & & 2,6 & 1,0 & & & 3,2 & 1,1 & & \\
\hline \multicolumn{18}{|l|}{ Yaş } \\
\hline $18-23$ & 12 & 3,1 & 0,7 & \multirow{6}{*}{10,7} & \multirow{6}{*}{0,06} & 3,8 & 1,1 & \multirow{6}{*}{13,3} & \multirow{6}{*}{$\begin{array}{l}0,0 \\
2\end{array}$} & 2,1 & 0,4 & \multirow{6}{*}{7,0} & & 3,8 & 1,1 & & \\
\hline $24-29$ & 75 & 3,0 & 0,7 & & & 3,2 & 1,1 & & & 2,6 & 1,0 & & & 3,1 & 1,1 & & \\
\hline $30-39$ & 93 & 3,1 & 0,7 & & & 3,4 & 1,1 & & & 2,7 & 0,9 & & 0,2 & 3,0 & 1,1 & 93 & \\
\hline $40-49$ & 29 & 3,4 & 0,6 & & & 3,9 & 1,0 & & & 2,7 & 1,1 & & 2 & 3,5 & 1,1 & 9,3 & 0,10 \\
\hline $50-59$ & 6 & 3,5 & 1,1 & & & 3,9 & 1,5 & & & 3,2 & 1,3 & & & 2,9 & 1,3 & & \\
\hline 60 ve üstü & 1 & 3,4 & 0,0 & & & 4,0 & 0,0 & & & 3,0 & 0,0 & & & 2,5 & 0,0 & & \\
\hline Eğitim Seviyes & & & & & & & & & & & & & & & & & \\
\hline İlkokul & 3 & 3,8 & 0,3 & & & 4,3 & 0,3 & & & 3,7 & 0,7 & & & 2,5 & 0,0 & & \\
\hline Ortaokul & 1 & 4,2 & 0,0 & & & 5,0 & 0,0 & & & 2,8 & 0,0 & & & 5,0 & 0,0 & & \\
\hline Lise & 36 & 3,4 & 0,6 & & & 3,9 & 1,1 & & & 2,8 & 0,9 & & & 3,4 & 1,2 & & \\
\hline Ön lisans & 30 & 3,3 & 0,7 & 31,4 & 0,00 & 3,6 & 1,1 & 23,0 & 0,0 & 3,0 & 1,2 & 15,9 & 0,0 & 3,2 & 1,2 & 18,4 & 0,01 \\
\hline Lisans & 100 & 3,1 & 0,6 & & & 3,4 & 1,0 & & & 2,5 & 0,9 & & & 3,3 & 1,0 & & \\
\hline Yüksek Lisans & 42 & 2,7 & 0,7 & & & 2,9 & 1,0 & & & 2,4 & 1,0 & & & 2,6 & 1,0 & & \\
\hline Doktora & 4 & 3,3 & 1,1 & & & 2,9 & 1,5 & & & 4,0 & 0,6 & & & 2,6 & 1,1 & & \\
\hline
\end{tabular}

\begin{tabular}{|c|c|c|c|c|c|c|c|c|c|c|c|c|c|c|c|c|c|}
\hline & & \multicolumn{4}{|c|}{ Örgütsel Bağlılık } & \multicolumn{4}{|c|}{ Duygusal Bağlılık } & \multicolumn{4}{|c|}{ Devam Bağlılık } & \multicolumn{4}{|c|}{ Normatif Bağlılık } \\
\hline & $\mathrm{n}$ & Ort & SS & Test & $p$ & Ort & SS & Test & $p$ & Ort & SS & Test & $p$ & Ort & SS & Test & $p$ \\
\hline \multicolumn{18}{|l|}{$\begin{array}{l}\text { Kurumda } \\
\text { Çalışma } \\
\text { Süresi }\end{array}$} \\
\hline 2 yıldan az & 54 & 3,0 & 0,7 & \multirow{8}{*}{17,1} & \multirow{8}{*}{0,01} & \begin{tabular}{|l|}
3,3 \\
\end{tabular} & 1,1 & \multirow{8}{*}{19,5} & \multirow{8}{*}{0,00} & 2,6 & 0,9 & \multirow{8}{*}{4,1} & \multirow{8}{*}{$\begin{array}{l}0, \\
67\end{array}$} & 3,1 & 1,2 & \multirow{8}{*}{5,6} & \multirow{8}{*}{0,47} \\
\hline $2-4$ yil & 62 & 2,9 & 0,7 & & & 3,2 & 1,0 & & & 2,6 & 1,0 & & & 3,0 & 1,1 & & \\
\hline $5-7$ y1l & 40 & 3,2 & 0,7 & & & 3,3 & 1,1 & & & 3,0 & 1,1 & & & 3,1 & 1,0 & & \\
\hline $8-10$ yil & 28 & 3,4 & 0,7 & & & 3,9 & 0,9 & & & 2,7 & 0,9 & & & 3,5 & 0,9 & & \\
\hline $11-15$ yil & 17 & 3,2 & 0,7 & & & 3,6 & 1,2 & & & 2,6 & 0,9 & & & 3,4 & 1,3 & & \\
\hline $16-20$ y1l & 8 & 3,6 & 0,4 & & & 4,5 & 0,5 & & & 2,7 & 1,2 & & & 3,4 & 1,3 & & \\
\hline $21-29$ y1l & 7 & 3,0 & 0,8 & & & 3,3 & 1,7 & & & 2,5 & 0,9 & & & 3,1 & 1,5 & & \\
\hline 30 ve üstü & 0 & 0,0 & 0,0 & & & 0,0 & 0,0 & & & 0,0 & 0,0 & & & 0,0 & 0,0 & & \\
\hline \multicolumn{18}{|l|}{ Unvan } \\
\hline İşçi & 53 & 3,2 & 0,8 & \multirow{8}{*}{9,2} & \multirow{8}{*}{0,16} & 3,5 & 1,3 & \multirow{8}{*}{6,9} & \multirow{8}{*}{0,33} & 2,9 & 1,07 & \multirow{8}{*}{9,1} & \multirow{8}{*}{$\begin{array}{l}0, \\
17\end{array}$} & 3,2 & 1,2 & \multirow{8}{*}{5,7} & \multirow{8}{*}{0,45} \\
\hline Memur & 32 & 3,1 & 0,5 & & & 3,4 & 0,7 & & & 2,8 & 0,91 & & & 3,1 & 1,0 & & \\
\hline Asistan & 7 & 3,2 & 0,6 & & & 3,3 & 1,4 & & & 3,3 & 0,94 & & & 2,6 & 1,4 & & \\
\hline $\begin{array}{l}\text { Uzman } \\
\text { Yardımcisı }\end{array}$ & 8 & 2,8 & 0,7 & & & 3,1 & 1,1 & & & 2,5 & 0,85 & & & 3,0 & 1,0 & & \\
\hline Uzman & 62 & 3,0 & 0,6 & & & 3,3 & 1,0 & & & 2,5 & 0,92 & & & 3,1 & 0,9 & & \\
\hline $\begin{array}{l}\text { Müdür } \\
\text { Yardımcısı }\end{array}$ & 22 & 3,3 & 0,6 & & & 3,8 & 0,8 & & & 2,6 & 0,84 & & & 3,6 & 1,1 & & \\
\hline Müdür & 32 & 3,0 & 0,9 & & & 3,4 & 1,4 & & & 2,4 & 1,09 & & & 3,1 & 1,3 & & \\
\hline Diğer & 0 & 0,0 & 0,0 & & & 0,0 & 0,0 & & & 0,0 & 0,0 & & & 0,0 & 0,0 & & \\
\hline
\end{tabular}

Tablo 7'deki sonuçlara göre cinsiyete göre örgütsel bağlllık, duygusal bağlllık, devam bağllı̆̆g ve normatif bağlılık puanlarının kadın ve erkekler arasında bir fark göstermediği $(p \geq 0,05)$ görülmektedir. Medeni duruma göre ise yine örgütsel bağlllık, duygusal bağlılık, devam bağlllığı ve normatif bağlllık puanlarının farklılaşmadığı $(\mathrm{p} \geq 0,05)$ görülmüştür. Yaş grubuna göre ortalama puanlar ve Mann Whitney $U$ testleri incelendiğinde örgütsel bağl1lık, devam bağlılığ ve normatif bağlılık puanlarının yaş grupları arasında farklılaşmadığı sadece duygusal bağlılık puanlarının ortalamasının yaş gruplarına göre değiştiği görülmüştür $(\mathrm{p}<0,05)$. 40-49 yaş aralığındaki çalışanların duygusal bağllılı puanlarının 24-29 yaş gruplarındakilere göre daha yüksek olduğu görülmektedir. Eğitim seviyesine göre ise örgütsel bağlllık, duygusal bağlllık, devam bağlllığ1 ve normatif bağl1lık ortalamalarının farklılaştığ1 görülmektedir $(p<0,05)$. Örgütsel bağlllı̆ın yüksek lisans seviyesinde daha alt seviyedeki eğitim seviyesindekilere göre düşük olduğu Mann Whitney U testi sonucunda gözlemlenmiştir. Duygusal bağlılığın ise lise seviyesinde yüksek lisans seviyesinden daha yüksek olduğu görülmüştür. Son olarak 
normatif bağlllık ise lisans seviyesinde yüksek lisans seviyesinden daha yüksek bulunmuştur. Kurumda çalışma süresine göre puanlar incelendiğinde örgütsel bağlllık ve duygusal bağlllık puanlarının kurumda çalışma süresine göre farklılaştı̆g $(p<0,05)$, devam bağlılığ ve normatif bağl1lık puanlarının kurumda çalışma süresine göre farklılaşmadığı görülmüştür $(\mathrm{p} \geq 0,05)$. Duygusal bağlllık puanları incelendiğinde Mann Whitney $U$ testi sonucunda 2 yıldan az çalışanların 16-20 yıl arasında çalışanlardan daha az duygusal bağllık ortalamasına sahip olduğu, 2-4 yıl arasında çalışanların 8-10 ve 16-20 yıl arasında çalışanlardan daha az duygusal bağlılık puanlarının olduğu görülmektedir. Yine 5-7 yıl arasında çalışanların duygusal bağlılık puanlarının 16-20 yıl arasında çalışanların duygusal bağlılık puanlarından daha az olduğu görülmüştür. Örgütsel bağlılık puanlarının ise kurumda çalışma süresi 2-4 yıl arasında olanlarda 16-20 yıl arasında çalışanlardan daha düşük olduğu gözlemlenmiştir. Çalışanların unvanına göre ise örgütsel bağlılık, duygusal bağlılık, devam bağlılığı ve normatif bağllık puanlarının değişmediği gözlemlenmiştir $(\mathrm{p} \geq 0,05)$. Bu sonuçlara göre $\mathrm{H}_{7}, \mathrm{H}_{8}$ ve $\mathrm{H}_{12}$ hipotezlerinin desteklenmediği, $\mathrm{H}_{9}, \mathrm{H}_{10}$ ve $\mathrm{H}_{11}$ hipotezlerinin desteklendiği görülmektedir.

Farklılık analizinden sonra motivasyon araçları ve örgütsel bağlllık arasındaki ilişkinin incelenmesi açısından parametrik olmayan korelasyon katsayılarından olan Spearman korelasyon katsayıları hesaplanmış ve sonuçları Tablo 7'de verilmiştir.

Tablo 8: Çalışanların Örgütsel Bağlılık ve Motivasyon Araçları Ölçeklerinden Aldıkları Puanlar Arasında İlişkinin İncelenmesi $(\mathrm{n}=216)$

\begin{tabular}{|c|c|c|c|c|c|c|c|c|}
\hline & & $\begin{array}{l}\text { Örgütsel } \\
\text { Bağlılık }\end{array}$ & $\begin{array}{l}\text { Duygusal } \\
\text { Bağl1lık }\end{array}$ & $\begin{array}{l}\text { Devam } \\
\text { Bağlilık }\end{array}$ & $\begin{array}{l}\text { Normatif } \\
\text { Bağlılık }\end{array}$ & $\begin{array}{l}\text { Motivasyon } \\
\text { Araçları }\end{array}$ & $\begin{array}{l}\text { İçsel } \\
\text { Motivasyon } \\
\text { Araçları }\end{array}$ & $\begin{array}{l}\text { Dişsal } \\
\text { Motivasyon } \\
\text { Araçları }\end{array}$ \\
\hline \multirow{2}{*}{$\begin{array}{l}\text { Örgütsel } \\
\text { Bağlılık }\end{array}$} & $\begin{array}{l}\text { Korelasyon } \\
\text { Katsayisi }\end{array}$ & 1,00 & & & & & & \\
\hline & $p$ & & & & & & & \\
\hline \multirow{2}{*}{$\begin{array}{l}\text { Duygusal } \\
\text { Bağlilık }\end{array}$} & $\begin{array}{l}\text { Korelasyon } \\
\text { Katsayisi }\end{array}$ & 0,82 & 1,00 & & & & & \\
\hline & $p$ & 0,00 & & & & & & \\
\hline \multirow{2}{*}{$\begin{array}{l}\text { Devam } \\
\text { Bağlilık }\end{array}$} & $\begin{array}{l}\text { Korelasyon } \\
\text { Katsayis1 }\end{array}$ & 0,38 & $-0,11$ & 1,00 & & & & \\
\hline & $p$ & 0,00 & 0,12 & & & & & \\
\hline \multirow{2}{*}{$\begin{array}{l}\text { Normatif } \\
\text { Bağlılık }\end{array}$} & $\begin{array}{l}\text { Korelasyon } \\
\text { Katsayis1 }\end{array}$ & 0,63 & 0,66 & $-0,15$ & 1,00 & & & \\
\hline & $p$ & 0,00 & 0,00 & 0,03 & & & & \\
\hline \multirow{2}{*}{$\begin{array}{l}\text { Motivasyon } \\
\text { Araçları }\end{array}$} & $\begin{array}{l}\text { Korelasyon } \\
\text { Katsayis1 }\end{array}$ & 0,28 & 0,33 & $-0,07$ & 0,30 & 1,00 & & \\
\hline & $p$ & 0,00 & 0,00 & 0,31 & 0,00 & & & \\
\hline \multirow{2}{*}{$\begin{array}{l}\text { İçsel } \\
\text { Motivasyon } \\
\text { Araçları }\end{array}$} & $\begin{array}{l}\text { Korelasyon } \\
\text { Katsayis1 }\end{array}$ & 0,27 & 0,36 & $-0,11$ & 0,31 & 0,75 & 1,00 & \\
\hline & $p$ & 0,00 & 0,00 & 0,10 & 0,00 & 0,00 & & \\
\hline \multirow{2}{*}{$\begin{array}{l}\text { Dişsal } \\
\text { Motivasyon } \\
\text { Araçları }\end{array}$} & $\begin{array}{l}\text { Korelasyon } \\
\text { Katsayis1 }\end{array}$ & 0,24 & 0,27 & $-0,02$ & 0,25 & 0,90 & 0,46 & 1,00 \\
\hline & $p$ & 0,00 & 0,00 & 0,74 & 0,00 & 0,00 & 0,00 & \\
\hline
\end{tabular}

Tablo 8 incelendiğinde örgütsel bağlılığın duygusal bağlılık, devam bağlllığı, normatif bağlllık, motivasyon araçları, içsel ve dışsal motivasyon araçları ile arasında pozitif ve anlamlı bir ilişki var olduğu görülmektedir $(\mathrm{p}<0,05)$. Başka bir deyişle örgütsel bağlılık arttığında bu değerlerde de artma gözlemlenmektedir (tersi de geçerlidir). Bu durumda özellikle "Örgütsel bağhllk ve motivasyon araçlar arasında ilişki vardır" şeklinde belirtilen $\mathrm{H}_{13}$ hipotezinin desteklendiği görülmektedir. Yine benzer şekilde duygusal bağlılık normatif bağlılık, motivasyon araçları, içsel ve dişsal motivasyon araçları ile anlamlı ve pozitif bir ilişkidedir $(\mathrm{p}<0,05)$. Devam bağlılığın ise normatif bağlılık ve arasındaki ilişki negatif ve anlamlıdır $(\mathrm{p}<0,05)$. Başka bir deyişle devam bağlılı̆ıın artması durumunda normatif bağlllık azalmaktadır. Normatif bağlılık ile motivasyon araçları, içsel ve dışsal motivasyon araçları arasında pozitif ve anlamlı ilişki bulunmuştur $(\mathrm{p}<0.05)$. Motivasyon araçlarının kendi alt boyutları ile arasında pozitif ve anlamlı ilişki varken yine alt boyutlarının arasındaki ilişkiler de pozitif ve anlamlıdır $(p<0,05)$.

Motivasyon araçları ve örgütsel bağlılık arasındaki ilişki incelendikten sonra bu ilişkinin tek yönlü olup olmadığının incelenmesi için regresyon analizi yapılmış ve sonuçları Tablo 9'da verilmiştir. Regresyon analizi sonuçlarına göre çift yönlü nedensellik ilişkisi anlamlı bulunmuştur. Bu durumda aralarındaki korelasyon ilişki geçerlidir. Başka bir deyişle örgütsel bağlılı̆̆ın artması motivasyon araçlarını arttırmakta ve motivasyon araçlarının artması örgütsel bağlılı̆̆ı arttırmaktadır. 
Tablo 9: Motivasyon Araçları ve Örgütsel Bağlllık Regresyon Modeli

\begin{tabular}{|l|l|l|l|l|l|l|l|}
\hline & Katsayı & Standart Hata & $\mathbf{t}$ & $\boldsymbol{p}$ & $\mathbf{R}^{\mathbf{2}}$ & $\mathbf{F}$ & $\boldsymbol{p}$ \\
\hline Bağımlı Değişken: Örgütsel Bă̆lılık & & & & & & & \\
\hline Sabit & 0,94 & 0,53 & 1,77 & 0,08 & 0,07 & 16,44 & 0,00 \\
\hline Motivasyon Araçları & 0,75 & 0,19 & 4,06 & 0,00 & & & \\
\hline Bă̆ımlı Değişken: Motivasyon Araçları & & & & & & & \\
\hline Sabit & 2,57 & 0,07 & 34,55 & 0,00 & 0,07 & 16,44 & 0,00 \\
\hline Örgütsel Bağlılık & 0,09 & 0,02 & 4,06 & 0,00 & & & \\
\hline
\end{tabular}

$\mathrm{Bu}$ araştırmada Türkiye'nin önemli perakende şirketlerinden birinin çalışanlarına göre motivasyon araçları ve örgütsel bağlllık arasındaki ilişki incelenmiş ve demografik özelliklere göre bu ölçeklerdeki farklılıklar analiz edilmiştir. Buna göre araştırma sonucunda korelasyon, regresyon ve farklılık testlerine göre önemli sonuçlar şu şekilde özetlenebilir:

- Cinsiyete göre motivasyon araçları, içsel ve dışsal motivasyon araçlarının kadınlarda bu puanların daha yüksek olduğu gözlemlenmiştir.

- İçsel motivasyon araçlarının ortalamasının evlilerde daha yüksek olduğu görülmüştür.

- 18-23 yaş grubundakilerin 24-19 yaş grubundakilerden ve 30-39 yaş grubundakilerden; 50-59 yaş grubundakilerin 24-29 ve 30-39 yaş grubundakilerinden motivasyon ve dışsal motivasyon araçları puanlarının ortalamasının daha yüksek olduğu gözlemlenmiştir.

- 40-49 yaş aralığındaki çalışanların duygusal bağlılık puanlarının 24-29 yaş gruplarındakilere göre daha yüksek olduğu görülmüştür.

- Örgütsel bağlllığın yüksek lisans seviyesinde daha alt seviyedeki eğitim seviyesindekilere göre düşük olduğu gözlemlenmiştir. Duygusal bağlılığın ise lise seviyesinde yüksek lisans seviyesinden daha yüksek olduğu görülmüsstür. Son olarak normatif bağlllık ise lisans seviyesinde yüksek lisans seviyesinden daha yüksek bulunmuştur.

- Duygusal bağlılık puanları incelendiğinde 2 yıldan az çalışanların 16-20 yıl arasında çalışanlardan daha az duygusal bağlılık ortalamasına sahip olduğu, 2-4 yıl arasında çalışanların 8-10 ve 16-20 yıl arasında çalışanlardan daha az duygusal bağlılık puanlarının olduğu görülmüştür. Yine 5-7 yıl arasında çalışanların duygusal bağlılık puanlarının 16-20 yıl arasında çalışanların duygusal bağlılık puanlarından daha az olduğu görülmüş̧ür. Örgütsel bağlllık puanlarının ise kurumda çalışma süresi 2-4 yıl arasında olanlarda 16-20 yıl arasında çalışanlardan daha düşük olduğu gözlemlenmiştir.

- Örgütsel bağlllığın duygusal bağlılık, devam bağlılığı, normatif bağlılık, motivasyon araçları, içsel ve dışsal motivasyon araçları ile arasında pozitif ve anlamlı bir ilişki var olduğu görülmüştür.

- Motivasyon araçları ile örgütsel bağlılık, duygusal bağll1ık, normatif bağllık, içsel motivasyon ve dışsal motivasyon ile arasında pozitif ve anlamlı bir ilişki var olduğu görülmüştür.

- Motivasyon araçları ve örgütsel bağlılık arasındaki ilişki tek yönlüden ziyade çift yönlü ve anlamlidir.

Kadınların erkeklerden motivasyonunun daha yüksek olması perakende sektöründeki motive edici insan kaynakları uygulamalarının sonucunun kadın çalışanlarda daha olumlu sonuçlanacağını göstermektedir. Motivasyon araçları ile örgütsel bağlılık arasındaki pozitif ve anlamlı ilişki göz önünde bulundurulduğunda da ilgili şirkette kadın çalışanlara yönelik motive edici politikalar kadın çalışanların memnuniyetini arttırarak daha motive edecek ve örgütsel bağlılığın artmasına neden olacaktır.

Başka bir açıdan bu sonuç erkek çalışanlara yönelik özel motivasyon araçlarının uygulanması gerektiğine dair de bir göstergedir. Yine motivasyon bakımından 18-23 yaş grubundakilerin 24-19 yaş grubundakilerden ve 30-39 yaş grubundakilerden; 50-59 yaş grubundakilerin 24-29 ve 30-39 yaş grubundakilerinden daha yüksek motivasyonun olduğunun bulunması motivasyonun genç yaşta başta yüksekken sonra azaldığının emekliliğe doğru ise tekrar arttığının göstergesidir. Bu durumda perakende sektöründe genç yaştaki insanlara yönelik motivasyon arttırıcı politikalara ihtiyaç olduğu görülmektedir. Bu sonuçlarda motivasyonun kuşaklar arasındaki farklılığı da incelenebilir. Y kuşağının motivasyonlarında düşüklük görülmektedir. 


\section{Sonuç}

Perakende sektörü Türkiye'de gelişmekte olan ve hizmet ve satın alma seçeneklerini sunarak birçok insana istihdam sağlayan bir sektördür. Bu nedenle perakende sektörünün çalışanlarının motivasyon ve örgütsel bağlılık ilişkilerinin incelenmesi önem taşımaktadır. Sektörün çalışanlarının yüksek motivasyon ve örgütsel bağlılığa sahip olması sektörün devamlılı̆̆ını ve büyümesini sağlayan etkenlerden biri olacaktır. Ayrıca çalışanların motivasyon araçları ve örgütsel bağlılıklarına göre farklılık ve benzerlik analizi yapılarak incelenmesi sektörde yer alan işverenlere yol gösterecek ve insan kaynakları politikalarına bu durum iyileştirmeler şeklinde yansıyacaktır.

Literatürde yapılan çalışmalar incelendiğinde ise sonuçları destekleyici çalışmaların yanında sonuçlarla çelişen çalışmalara da ulaşılabilmektedir. Örneğin, Bilge ve arkadaşları (2015) dişsal motivasyon örgütsel bağlllı̆̆ın alt faktörleri üzerinde pozitif etkiye sahip iken içsel motivasyonun örgütsel bağlıllı̆ın alt faktörleri üzerinde negatif etkiye sahip olduğu sonucuna ulaşılmışlardır. Bu çalışmada hem içsel hem de dışsal motivasyon araçlarının örgütsel bağlılığın alt faktörlerinde (devam bağllığı haricinde) pozitif ve anlamlı etkisi olduğu görülmüştür. Başka bir çalışmada ise Keskin (2019) örgütsel bağlllık ile motivasyon faktörlerini oluşturan boyutlar arasında pozitif yönlü anlamlı ilişki olduğu sonucuna ulaşılmıştır. Bu sonuç ise bu çalışmadaki sonuçlarla benzerlik göstermektedir. Bu çalışma da benzer şekilde motivasyon araçları ile örgütsel bağlılık, duygusal bağlılık, normatif bağlllık, içsel motivasyon ve dışsal motivasyon ile arasında anlamlı ve pozitif bir ilişki olduğu görülmüştür. Daha önce de bahsedildiği gibi literatürde yapılan çalışmalar gerek uygulandığı sektör gerekse zaman bakımından farklılık gösterdiğinden elde edilen sonuçlar da birbirinden farklılaşsa da genel olarak elde edilen sonuçlar da motivasyon araçlarının örgütsel bağlılığı arttırıcı yönde etkisi olduğunu söylemektedir. Bu bilgiler ışığında, sektör yöneticilerine çalışanların duygusal bağlılıklarını ve içsel motivasyonlarını arttırmak için öncelikli olarak içsel motivasyon araçlarını başarı ile uygulamaları önerilir. Bu doğrultuda eğitim ve gelişim faaliyetlerine önem vermeleri, terfi ve kariyer plânlaması yapmaları, çalışan takdir ve ödüllendirme programlarına yer vermeleri gerekir.

Örgütsel bağlllığın açısından ise yüksek lisans seviyesinde daha alt seviyedeki eğitim seviyesindekilere göre düşük örgütsel bağlılığın olması eğitim düzeyi arttıkça bağlılığın azaldığına işaret etmektedir. Bu durumda eğitim seviyesi yüksek olan çalışanlara yönelik farklı bir insan kaynakları politikaları uygulanarak örgütsel bağlılıkları sağlamlaştırılmalıdır. Duygusal bağlılık açısından ise 2 yıldan daha az çalışanların 16-20 yıl arasında çalışanlardan daha az duygusal bağlılığa sahip olması; 2-4 yıl arasında çalışanların 8-10 ve 16-20 yıl arasında çalışanlardan daha az duygusal bağlılık puanlarına sahip olması ve 5-7 yıl arasında çalışanların duygusal bağllıklarının 16-20 yıl arasında çalışanların duygusal bağll1ıklarından daha az olması duygusal örgütsel bağlılı̆̆ın aynı şirkette zamansal olarak daha fazla çalıştıkça arttığını göstermektedir. Şirkette daha fazla çalışanlar daha çok duygusal olarak bağlılık kurmaktadır. Bu durum beklenen bir durumdur. Fakat tecrübe yılı daha az olan çalışanlara yönelik örgütsel bağlılığın artırılmasına yönelik politikalara ihtiyaç duyulmaktadır. Bu ve bunun gibi farklılıklara yönelik politikaların uygulanması motivasyon araçları ve örgütsel bağlılık arasındaki pozitif çift yönlü ilişkinin olması nedeniyle domino etkisi yaratarak örgütsel bağlılık ve motivasyonun yükselmesine neden olacaktır.

Araştırmanın sınırlılıkları olarak, çalışanların bazı soruları anlamakta zorlanması, perakende sektöründe çalışanların yoğun çalışma saatleri yaşamasından dolayı çalışanların anketi doldurmasında gereken zamanı bulmasında güçlük çekilmiş olması veri toplanma süresini uzatmıştır. Bu çalışma perakende sektörüne yönelik bir uygulama olduğundan bu sektördeki insan kaynakları yöneticilerinin yararlanacağı bir çalışma olacağı düşünülmektedir. Ayrıca bu çalışmaya başka ölçekler de dâhil edilerek gelecek çalışmalarda daha ayrıntılı ilişkiler incelenebilir.

\section{Hakem Değerlendirmesi / Peer-review:}

Diş bağımsız

Externally peer-reviewed

\section{Çıkar Çatışması / Conflict of interests:}

Yazar(lar) çıkar çatışması bildirmemiştir.

The author(s) has (have) no conflict of interest to declare. 


\section{Finansal Destek / Grant Support:}

Yazar(lar) bu çalışma için finansal destek almadı̆̆ını beyan etmiştir.

The author(s) declared that this study has received no financial support.

\section{Yazar Katkıları / Author Contributions:}

Fikir/Kavram/Tasarım - Idea/Concept/Design: M.Y., P.V. Veri Toplama ve/veya İşleme - Data Collection and/or Processing: M.Y. Analiz ve/veya Yorum - Analysis and/or Interpretation: M.Y. Kaynak Taramas1 Literature Review: M.Y., P.V., Makalenin Yazımı - Writing the Article: M.Y., P.V. Eleştirel İnceleme Critical Review: M.Y., P.V. Onay - Approval: M.Y., P.V.

\section{Kaynakça / References}

Alderfer, C.P. (1969). "An Empirical Test of a New Theory of Human Needs”, Organizational Behaviour and Human Performance, (4), 142-75.

Allen, R.S. ve Kilmann, R.H. (2001). “The Role of The Reward System for a Total Quality Management Based Strategy", Journal of Organizational Change. 14(2), 110-131

Barles, M. (2016). “İşgörenlerin Motivasyon Araçlarını Algılaması Düzeyinin Belirlenmesine Yönelik Karşılaştırmalı Bir Araştırma Sağlık Bakanlığında Uygulama”. (Yayınlanmamış Yüksek Lisans tezi). Gazi Üniversitesi, Eğitim Bilimler Enstitüsü, Ankara.

Batmaz, Ş. (2002).“Örgütlerde Motivasyonun Önemi ve Başarıya Etkisi”, Standart: Ekonomik ve Teknik Dergi, (491), 45-48.

Becker, H.S. (1960). "Notes on The Concept of Commitment”, American Journal of Sociology, (66), 32-42.

Bilge, H., Bal, V. ve Gönlügür, A. (2015). “İçsel-Dışsal Motivasyon İle Örgütsel Bağlılık Arasındaki İlişkinin Araştırılması", Maliye ve Finans Yazıları, 1 (104) , 83-104. Retrieved From Https:/ /Dergipark.Org.Tr/Tr/Pub/Mfy/İssue/16277/170738

Bolat, O. İ. ve Bolat, T. (2008). “Otel İşletmelerinde Örgütsel Bağlılık Ve Örgütsel Vatandaşlık Davranışı İlişkisi”, Balıkesir Üniversitesi Sosyal Bilimler Enstitüsü Dergisi, 11(19), 75-94.

Brislin, R. W., Kabigting, F., Macnab, B., Zukis, B. ve Worthley, R. (2005), Evolving Perceptions of Japanese Workplace Motivation, International Journal of Cross Cultural Management. 5 (1), 87-103.

Canbaba, İ.E. (2019). “İş Görenlerin Motivasyonu ile Örgütsel Bağlılıkları Arasındaki İlişki: Erzincan Ve Erzurum'daki Üç, Dört Ve Beş Yıldızlı Otellerde Bir Çalışma”. (Yayınlanmamış Yüksek Lisans tezi). Binali Yıldırım Üniversitesi, Sosyal Bilimler Enstitüsü, Erzincan.

Çöğür, H. Ç. (2010). “İnşaat Sektöründe Proje Yönetiminin Kullanabileceği Motivasyon Araçları".(Yayınlanmamış Yüksek Lisans tezi). Çukurova Üniversitesi, Fen Bilimleri Enstitüsü, Adana.

Dündar, S., Özutku, H. ve Taşpınar, F. (2007). “İçsel ve dişsal motivasyon araçlarının işgörenlerin motivasyonu üzerindeki etkisi: Ampirik bir inceleme", Gazi Üniversitesi Ticaret ve Turizm Ĕ̆itim Fakültesi Dergisi, (2), 105-119.

Eren, H. (1997). Toplam Kalite ve İnsan Kaynakları Yönetimi. 2. Baskı, İstanbul: Alfa Yayınları.

Ertit, R. (2019). “Motivasyon, Kişilik Özellikleri ve Örgütsel Bağlılık Arasındaki İlişkilerin İncelenmesi: Kastamonu İlinde Bir Araştırma". (Yayınlanmamış Yüksek Lisans Tezi). Kastamonu Üniversitesi, Sosyal Bilimler Enstitüsü, Kastamonu.

Genç, N. (2004). Yönetim ve Organizasyon: Çă̆daş Sistemler ve Yaklaşımlar, Ankara: Seçkin Yayınları.

Gülova, A.A. ve Demirsoy, Ö. (2012). Örgüt Kültürü ve Örgütsel Bağlılık Arasındaki İlişki: Hizmet Sektörü Çalışanları Üzerinde Ampirik Bir Araştırma. Business and Economics Research Journal. 3(3).

Hair, J., Black, W., Babin, B. ve Anderson, R. (2010). Multivariate data analysis (7th ed.): Prentice-Hall, Inc. Upper Saddle River, NJ, USA. 
Herzberg, F., Mausner, B. ve Snyderman BB.(1993). The Motivation to Work Somerset.

İnce M. ve Gül H. (2005). Yönetimde Yeni Bir Paradigma: Örgüsel Bağhllık. Çizgi Kitabevi Yayınları.

Kalaycı, N. (2010). “Yükseköğretimde proje tabanlı öğrenmeye ilişkin bir uygulama projeyi yöneten öğrenciler açısından analiz", Eğitim ve Bilim, 33(147), 85-105.

Keskin, M.Ş. (2019). “Sosyal Güvenlik Çalışanlarında Motivasyonun Örgütsel Bağlılığa Etkisi Ve Sosyal Güvenlik Kurumu Ankara İl Müdürlüğü'nde Bir Uygulama”. (YayınlanmamışYüksek Lisans Tezi). Kırıkkale Üniversitesi, Sosyal Bilimler Enstitüsü, Kırıkkale.

KMPG (2018). https://assets.kpmg/content/dam/kpmg/tr/pdf/2018/01/sektorel-bakis-2018perakende.pdf Alındığı tarih: 19.04.2020.

Kondalkar, V.G. (2007). Organizational Behavior. New Delhi: New Age International (P) Ltd.

Luthans, F. (2011). Organizational behavior: an evidence-based approach. NewYork: McGraw-Hill Irwin .

Mahaney C. R. ve Lederer A. L. (2006). “The Effect of Intrinsic and Extrinsic Rewards for Developers on Information Systems Project Success", Project Management Journal. 37,(4),42-54.

McClelland, D.C. (1961). The Achieving Society. Princeton, NY: Nostrand.

Meyer, J. P. ve Allen N. J. (1984). “Testing The 'Side-Bet Theory' Of Organizational Commitment: Some Metodological Considerations”, Journal of Applied Psychology, 69 (3), 372-378.

Meyer, J.P. ve Allen, N.J. (1991). “A Three component Conceptualization Of Organizational Commitment", Human Resources Management Review, (1) ,61-89.

Mottaz J. C. (1985). “The Relative Importance of Intrinsic and Extrinsic Rewards as Determinants of Wok Satisfaction", The Sociological Quarterly, 26 (3), 365-385.

Mowday, R.T., Steers, R.M. ve Porter, L.W.(1979).“The Measurement Of Organizational Commitment”, Journal of Vocational Behavior. (14), 224-247.

PWC (2016). Dönüşürken Büyüyen Türkiye Perakende Sektörü. 2016 y1lı sektör raporu.

Razali, N. M. ve Wah, Y. B. (2011). “Power comparisons of shapiro-wilk, kolmogorov-smirnov, lilliefors and anderson-darling tests", Journal of statistical modeling and analytics, 2(1), 21-33.

Ryan, R.M. ve Deci, E.L. (2000).“Self-Determination Theory and the Facilitation of Intrinsic Motivation, Social Development, and Well-Being", American Psychologist, 55(1), 68-78.

Sabuncuoğlu, Z. ve Tüz, M. (2008). Örgütsel Psikoloji (4. Basım). Bursa: Alfa Aktüel Yayınevi.

Saraçlı, S., Keskınturk, T., Cicek, M. ve Gazeloglu, C. (2014). “Örgütsel Bağlılı̆̆ın Motivasyon Üzerındekı Etkilerinin Yapısal Eşitlik Modellemesı ile İncelenmesı: Türk Akademisyenler Örneği”, International Anatolia Academic Online Journal Sciences Journal, 2 (2) , 0-0.

Sarığlu, K. (2019). “Çalışan Motivasyonunu Artırma Araçlarının Örgütsel Bağlılık Üzerindeki Etkileri: Gıda Sektöründe Bir Alan Araştırması”. (Yayınlanmamış Yüksek Lisans Tezi). İstanbul Üniversitesi, Sosyal Bilimler Enstitüsü, İstanbul.

Steers, R.M., Mowday, R.T. ve Shapiro, D.L. (2004). “The Future of Work Motivation Theory”, Academy of Management Review, 29(3), 379-387.

Stumpf, S.A., Tymon Jr, W.G., Favorito, N. ve Smith, R.R. (2013). “Employees and Change İnitiatives: Intrinsic Rewards and Feeling Valued", Journal of Business Strategy, 34(2), 21-29.

Torun, M.T. (2013). “Örgütlerde İşgören Performansını Artırmada Kullanılan Motivasyon Araçlarının İncelenmesi ve Bir Uygulama", (Yayınlanmamış Yüksek Lisans Tezi). Ondokuzmayıs Üniversitesi Sosyal Bilimler Enstitüsü. Samsun.

Tulunay A. ve Ö, Buluç, B. (2018). “İlköğretim Öğretmenlerinde Motivasyon Ve Örgütsel Bağlılığın Demografik Değişkenler Açısından İncelenmesi". Mehmet Akif Ersoy Üniversitesi Eğitim Fakültesi Dergisi , (48) , 1-30.

Uygur, A. (2004). Örgütsel Bağlılık ve İşgören Performansı. Türkiye Vakıflar Bankası Ankara, İstanbul ve İzmir İli Şubelerine Yönelik Alan Araştırması. Hacettepe Üniversitesi, Ankara.

Wasti, A. (2003). “Kültürlerarası Çalışmalarda Yöntem: Örgütsel Bağlılık Yazınından Dersler”, Yönetim Araştırmaları Dergisi, 2 (3), 125-145. 
Wasti, S. A. (2000). Meyer ve Allen'in üç boyutlu örgütsel bağlllık ölçeğinin geçerlik ve güvenirlik analizi. 8. Ulusal Yönetim ve Organizasyon Kongresi.

Weinner,Y. ve Vardi, Y. (1980). Relationship between job, organization and career commitment and work outcomes: An Integrative Approach. Organizational Behavior and Human Performance, 26, 81-96.

Weiner, Y. (1982). "Commitment in organizations: A normative view", Academy of management review, 3 (7), 418-428.

Yüksel, Ö. (2000).İnsan kaynakları yönetimi. Ankara: Gazi Kitapevi.

Zorlu, A. (2019). "An analysis of organizational commitment of cabin crew in different generation, Sosyal Bilimler Enstitüsü", (Yayınlanmamış Yüksek Lisans Tezi). Yeditepe Üniversitesi, Istanbul. 